\title{
Modern isotope hydrology and controls on $\delta D$ of plant leaf waxes at Lake El'gygytgyn, NE Russia
}

\author{
K. M. K. Wilkie ${ }^{1, *}$, B. Chapligin ${ }^{2}$, H. Meyer ${ }^{2}$, S. Burns ${ }^{1}$, S. Petsch ${ }^{1}$, and J. Brigham-Grette ${ }^{1}$ \\ ${ }^{1}$ Department of Geosciences, University of Massachusetts, Amherst, MA, USA \\ ${ }^{2}$ Alfred Wegener Institute for Polar and Marine Research, Research Unit Potsdam, Potsdam, Germany \\ *now at: University of Toronto, Toronto, Canada
}

Correspondence to: K. M. K. Wilkie (kwilkie@es.utoronto.ca)

Received: 28 June 2012 - Published in Clim. Past Discuss.: 16 August 2012

Revised: 13 December 2012 - Accepted: 16 December 2012 - Published: 8 February 2013

\begin{abstract}
Stable isotope data from lipid biomarkers and diatom silica recovered from lake sediment cores hold great promise for paleoclimate and paleohydrological reconstructions. However, these records rely on accurate calibration with modern precipitation and hydrologic processes and only limited data exist on the controls on the $\delta \mathrm{D}$ values for $n$ alkanoic acids from plant leaf waxes. Here we investigate the stable isotopic composition of modern precipitation, streams, lake water and ice cover, and use these data to constrain isotope systematics of the Lake El'gygytgyn Basin hydrology. Compound-specific hydrogen isotope ratios determined from $n$-alkanoic acids from modern vegetation are compared with modern precipitation and lake core top sediments. Multispecies net (apparent) fractionation values between source water (precipitation) and modern vegetation (e.g., $\varepsilon_{\text {wax/precip }}$ mean value is $-107 \pm 12 \%$ o) agree with previous results and suggest a consistent offset between source waters and the $\delta \mathrm{D}$ values of alkanoic acids. We conclude that although there may be some bias towards a winter precipitation signal, overall $\delta \mathrm{D}$ values from leaf wax $n$-alkanoic acids record annual average precipitation within the El'gygytgyn Basin. A net fractionation calculated for 200-yr-integrated lake sediments yields $\varepsilon_{30 / \text { precip }}=-96 \pm 8 \%$ and can provide robust net "apparent" fractionation to be used in future paleohydrological reconstructions.
\end{abstract}

\section{Introduction}

Hydrogen isotope ratios $(\delta \mathrm{D})$ of lipid biomarkers are emerging as a new paleoclimatic and paleohydrological proxy (e.g., Sauer et al., 2001; Huang et al., 2002; Jacob et al., 2007; Feakins and Sessions, 2010; Castañeda and Schouten, 2011; Sachse et al., 2012 and references therein). Environmental water is the primary source of hydrogen for organic matter from photoautotrophic organisms; for terrestrial plants, this constitutes soil water that is ultimately derived from precipitation whereas aquatic organisms utilize lake water affected by lake hydrology. Multiple environmental variables affect the $\delta \mathrm{D}$ values of meteoric water such as temperature, elevation and water vapour source (Craig, 1961; Craig and Gordon, 1965; Dansgaard, 1964; Gonfiantini, 1986; Gat, 1996). The isotopic composition of meteoric water is also controlled by continental and "latitudinal effects" (Dansgaard, 1964; Craig, 1961; Gonfiantini, 1986; Gat, 1996; Bowen and Revenaugh, 2003; Kurita et al., 2004), which are reflected in the $\delta \mathrm{D}$ of plant leaf waxes $\left(\delta \mathrm{D}_{\mathrm{wax}}\right)$ (Sachse et al., 2006; Smith and Freeman, 2006; Hou et al., 2008; Liu and Yang, 2008; Polissar and Freeman, 2010). Previous research has tested the relationships between key hydrological variables and leaf wax lipid $\delta \mathrm{D}$ values from modern vegetation along climate gradients, yielding strong linear relationships of $\delta \mathrm{D}_{\text {wax }}$ with mean precipitation $\delta \mathrm{D}$ values (Sachse et al., 2004; Huang et al., 2004; Hou et al. 2008; Polissar and Freeman, 2010). Changes in sedimentary $\delta \mathrm{D}_{\text {wax }}$ have been interpreted as shifts in precipitation $\delta \mathrm{D}$ $\left(\delta \mathrm{D}_{\mathrm{p}}\right)$ (e.g., Liu and Yang, 2008; Tierney et al., 2008) or in 
evapotranspiration (Schefuß et al., 2005; Sachse et al., 2006; Jacob et al., 2007). However, while $\delta \mathrm{D}_{\text {wax }}$ is dependent on the $\delta \mathrm{D}$ of the source water, interpretations can be complicated by biosynthetic fractionations, evapotranspiration from soil and leaf water as well as physiological difference relating to plant life form (e.g., tree, shrub, grass) (Sessions et al., 1999; Liu and Yang, 2008; Smith and Freeman, 2006; Sachse et al., 2012).

In general, abundance and composition of biomarkers can serve to identify past ecosystems and environmental parameters during their formation (Meyers, 2003). Fatty acids such as long-chain even carbon-numbered $n$-alkanoic acids (e.g., > 24 carbon chain length) typically originate from leaf waxes of terrestrial plants (Eglinton and Hamilton, 1967; Cranwell, 1974; Cranwell et al., 1987). In contrast, shortchain even carbon-numbered $n$-fatty acids (i.e., $<20$ carbon atoms) are abundant as major constituents of cell membranes and waxes in many organisms, and their relative abundances have been attributed to phytoplanktonic and zooplanktonic sources (Cranwell, 1974; Cardoso et al., 1983; Cranwell et al., 1987; Meyers and Ishiwatari, 1993; Volkman et al., 1998). Aquatic photosynthetic organisms in lakes obtain hydrogen from lake water to produce their organic compounds, whereas terrestrial plants utilize hydrogen within the leaf water, which is subject to evapotranspiration (Leaney et al., 1985; Huang et al., 2004; Sachse et al., 2004; Zhang and Sachs, 2007). Thus, isotopically distinct source waters are used for the biosynthesis of aquatic versus terrestrial biomarkers (Sachse et al., 2006, 2012). Lake water hydrogen isotopic variations are driven by $\delta \mathrm{D}_{\mathrm{p}}$, lake hydrology, and the residence time of the lake water (i.e., Leng and Marshall, 2004; Jacob et al., 2007). Large, well-mixed lakes with long lake water residence times, such as modern Lake El'gygytgyn ( 120 yr; Fedorov et al., 2009, 2012), will “average out" short-term seasonal variations in precipitation and stream input isotopic compositions, and will reflect mean annual precipitation (Leng and Marshall, 2004; Nolan and Brigham-Grette, 2007). Leaf wax lipids derived from terrestrial plants instead record the isotopic ratio of soil water, which is ultimately recharged by precipitation. Snowmelt is typically the dominant annual hydrological event in Arctic watersheds (Kane et al., 1992), and within the El'gygytgyn Basin soil water is annually recharged by snowmelt (Nolan and Brigham-Grette, 2007; Fedorov et al., 2012).

Proxy use of $\delta \mathrm{D}_{\text {wax }}$ for paleoclimatic reconstructions depends on establishing a "net (or apparent) fractionation" between meteoric water and lipid $\delta \mathrm{D}$ values $\left(\varepsilon_{\mathrm{lipid} / \mathrm{w}}\right)$. Previous research has focused on $\delta \mathrm{D}$ values of $\mathrm{C}_{29} n$-alkanes (see Sachse et al., 2012 for review and global data set). However only a few studies have investigated factors affecting leaf wax $\delta \mathrm{D}$ values from $n$-alkanoic acids (Huang et al., 2004; Chikaraishi and Naraoka, 2007; Hou et al., 2007a, b). Yet an increasing number of paleoclimate studies utilize $\delta \mathrm{D}$ values from alkanoic acids for paleoclimate reconstructions (Tierney et al., 2008; Sun et al., 2011; Thomas et al., 2012).
Net fractionation values incorporate soil-water evaporation, leaf-water transpiration and biosynthetic fractionations (see Sachse et al., 2012 for review and references therein). Prior studies have shown smaller $\varepsilon_{\text {lipid/w }}$ values for lake sediments from arid regions ( $n$-alkanoic acids: Hou et al., 2008; $n$ alkanes: Polissar and Freeman, 2010) and for modern vegetation in drier vs. wetter sites ( $n$-alkanes: Smith and Freeman, 2006; Feakins and Sessions, 2010). These values may be offset due to transpiration (i.e., enrichment of leaf water) in semi-arid to arid environments that act to reduce $\varepsilon_{\text {lipid/w }}$, possibly after passing some threshold beyond, which $\varepsilon_{\text {lipid/w }}$ remains insensitive to increasing aridity ( $n$-alkanes: Smith and Freeman, 2006; Sachse et al., 2006, 2012; Yang et al., 2009; Feakins and Sessions, 2010: $n$-alkanoic acids: Hou et al., 2008).

In addition to variable climatic and/or biosynthetic drivers affecting net fractionations, large interspecies variability has been found at the individual plant scale (e.g., Chikaraishi and Naraoka, 2003; Liu and Huang, 2005; Hou et al., 2008), particularly in highly arid sites (Feakins and Sessions, 2010). Several studies have linked this variability to life form (e.g., tree, shrub, grass) (Liu et al., 2006; Liu and Yang, 2008; Sachse et al., 2012), leading to concern for the potential to bias paleoclimatic reconstructions given inevitable vegetation shifts in response to climatic change. However, Feakins and Sessions (2010) find a strong correlation between $\delta \mathrm{D}$ of source water and the average $\delta \mathrm{D}_{\text {wax }}$ value at a site suggesting catchment-scale average $\delta \mathrm{D}_{\text {wax }}$ values reliably record regional climate despite a large spread in values between individuals. This is in good agreement with other calibration studies using core-top sediments (e.g., Huang et al., 2004; Sachse et al., 2004; Hou et al., 2008) that show much better correlations to climate than studies of individual plants due to temporal and spatial integration of plant inputs.

Here we establish local relationships between the $\delta \mathrm{D}$ of modern vegetation, sediment traps and the $\delta \mathrm{D}$ in modern El'gygytgyn lake sediments as the context for reconstruction of El'gygytgyn Basin paleohydrology. We investigate the controls on alkanoic acid $\delta \mathrm{D}$ values as an increasing number of paleoclimate studies make use of this compound class. These studies are supplemented by isotopic analysis of samples of modern meteoric water, including winter and summer precipitation, streams, lake water and ice cover which provide insight into the modern isotope hydrology. This approach enables us to (i) determine the net fractionation $\left(\varepsilon_{\mathrm{wax} / \mathrm{w}}\right)$ between modern vegetation and source water within the El'gygytgyn Basin, (ii) assess the delivery of organic matter and target compounds for $\delta \mathrm{D}$ analysis, and (iii) establish a framework for separating variations in the isotopic composition of lake water from changes in the isotopic composition of precipitation in the $\delta \mathrm{D}_{\text {wax }}$ paleohydrological proxy. 


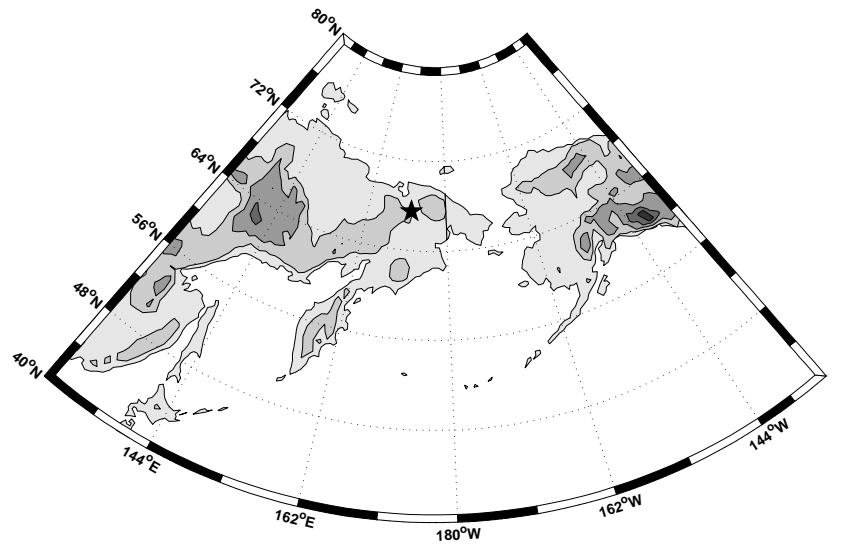

Fig. 1. Location of Lake El'gygytgyn (black star) in NE Russia.

\section{Study area: location and climate}

Lake El'gygytgyn is situated within a $3.58 \times 0.04 \mathrm{Ma}$ old meteorite crater (Layer, 2000) located in a previously unglaciated region of the far east Russian Arctic $\left(67^{\circ} 30^{\prime} \mathrm{N}\right.$, $172^{\circ} 05^{\prime}$ E; Glushkova and Smirnov, 2006; Fig. 1). The crater rim elevations vary between 600 and $930 \mathrm{~m}$, while the lake surface lies at $492 \mathrm{~m}$ above sea level. The crater is approximately $18 \mathrm{~km}$ in diameter with a total watershed area of $293 \mathrm{~km}^{2}\left(110 \mathrm{~km}^{2}\right.$ is lake surface), and the lake is $12 \mathrm{~km}$ wide and $175 \mathrm{~m}$ deep with a volume of $14.1 \mathrm{~km}^{3}$ (Nolan and Brigham-Grette, 2007). Water temperatures in this cold monomictic, ultra oligotrophic lake are $<4{ }^{\circ} \mathrm{C}$, and the lake is fed by 50 streams draining from within the crater rim (Cremer et al., 2005; Nolan and Brigham-Grette, 2007). Shallow lagoons with seasonal water temperatures $>6^{\circ} \mathrm{C}$ are dammed by gravel berms surrounding the lake edge (Nolan and Brigham-Grette, 2007). Mean annual air temperature measured from $2002-2008$ was $-10.4{ }^{\circ} \mathrm{C}$, and total precipitation rose from $350 \mathrm{~mm} \mathrm{a}^{-1}$ to about $550 \mathrm{~mm} \mathrm{a}^{-1}$ over this period with roughly equal rates between winter and summer precipitation (Nolan and Brigham-Grette, 2007; Nolan, 2012).

The El'gygytgyn Basin is located in a zone of hypoarctic tundra (Yurtsev, 1973), and modern vegetation within the basin is dominated by lichen and discontinuous herbaceous taxa (Kohzevnikov, 1993; Minyuk, 2005; Lozhkin et al., 2007). Salix and Poaceae species comprise the dominant woody and non-woody taxa, respectively, and modern tree line is located ca. $150 \mathrm{~km}$ to the south and west of the lake (Lozhkin et al., 2006).

\section{Methods}

\subsection{Sample collection}

\subsubsection{Water samples}

Lake water and precipitation samples were collected during the 2003 El'gygytgyn field expedition in $30 \mathrm{ml}$ Nalgene bottles and stabilized with one drop mercuric chloride (Juschus et al., 2005a). Water from incoming streams and the Enmyvaam outflow were likewise collected, and all water samples were stored at $4{ }^{\circ} \mathrm{C}$ at the Geoscience Dept., UMass Amherst, until analysis. Precipitation samples were also collected over the winter 2008-2009 (Table 1).

\subsubsection{Modern vegetation samples}

Herbarium specimens of typical modern plants growing close to the lake were sampled in summer 2003. Specimens were collected during summer 2003 for the purposes of establishing a standard pollen collection of the local vegetation at Lake El'gygytgyn (Minyuk, 2005). Subsamples $(\sim 0.5 \mathrm{~g})$ of seven representative specimens were removed from unfixed portions of the plants, rinsed with distilled water, dried at $40^{\circ} \mathrm{C}$, and homogenized with mortar and pestle. The total lipid extract (TLE) was separated into neutral and carboxylic acid fractions on a solid phase extraction (SPE) column containing $0.5 \mathrm{~g}$ of $\mathrm{DSC}-\mathrm{NH}_{2}$ stationary phase (Supelco). A neutral fraction was eluted with $4 \mathrm{~mL}$ hexane: dichloromethane DCM $(1: 1)$ and archived for future analysis. Fatty acids were eluted with $8 \mathrm{ml}$ of $2 \%$ formic acid in DCM and were subsequently derivatized as methyl esters (FAME) with $\mathrm{BF}_{3} \mathrm{MeOH}$.

\subsubsection{Sediment traps and sediment core tops}

Sediment traps were deployed during the spring field expedition, 2003 (Fig. 2). Each sediment trap consisted of a base plate made of plastic with a steel rod to fix the trap in vertical position at the rope. Four plastic tubes with a diameter of $46 \mathrm{~mm}$ were screwed to the bottom of this plate. The rope was anchored at the lake bottom with a bag filled with pebbles and kept up in the water column by buoys fixed beneath the base of the lake ice (Juschus et al., 2005b). Unfortunately, sediment traps were only recovered at one location during the 2003 expedition yielding only six samples.

Samples of the sediment water interface were also collected during the spring 2003 field expedition. Coring was carried out from a floating platform with a gravity corer; attention was paid to horizontal preservation of the sediment water interface. Twelve of these samples were selected for biomarker analysis, of which four samples were selected for further preparation for compound-specific isotopic analysis. Additionally, a sample from the upper $0-2 \mathrm{~cm}$ of a $16-\mathrm{m}$-long sediment core (LZ1024) was also isolated and prepared for 
Table 1. Mean values $\left(\delta^{18} \mathrm{O}, \delta \mathrm{D}\right.$, d-excess $)$ for $\mathrm{H}_{2} \mathrm{O}$ sample sets.

\begin{tabular}{lccccccc}
\hline $\begin{array}{l}\mathrm{H}_{2} \mathrm{O} \text { sample } \\
\text { sets }\end{array}$ & $\begin{array}{c}\delta^{18} \mathrm{O}(\% \circ) \\
\text { vs. VSMOW }\end{array}$ & $\mathrm{SD}(1)$ & $\begin{array}{c}\delta \mathrm{D}(\% \circ) \\
\text { vs. VSMOW }\end{array}$ & $\mathrm{SD}(1)$ & $\begin{array}{c}\delta^{18} \mathrm{O}(\% \circ) \\
\mathrm{OIPC}^{\mathrm{a}}\end{array}$ & $\begin{array}{c}\delta \mathrm{D}(\% \circ) \\
\mathrm{OIPC}^{\mathrm{a}}\end{array}$ \\
\hline Snow & -23.16 & 0.03 & -180 & 0.3 & 5.4 & $-21.4^{\mathrm{b}}$ & $-163^{\mathrm{b}}$ \\
Rain & -14.29 & 0.03 & -115 & 0.4 & -0.5 & $-15.4^{\mathrm{c}}$ & $-123^{\mathrm{c}}$ \\
Streams & -18.88 & 0.02 & -145 & 0.3 & 6.7 & & \\
Lake Ice & -19.27 & 0.02 & -151 & 0.4 & 3.1 & & \\
Lake profiles & -19.80 & 0.02 & -155 & 0.3 & 3.4 & & \\
\hline
\end{tabular}

a $95 \%$ confidence interval of model values determined from the Online Isotopes in Precipitation Calculator (OIPC), version 2.2

(Bowen and Revenaugh, 2003). ${ }^{b}$ Arithmetic mean of OIPC modelled monthly values for Siberian winter months (November-April)

${ }^{c}$ Arithmetic mean of OIPC modelled monthly values for Siberian summer months (June-August).

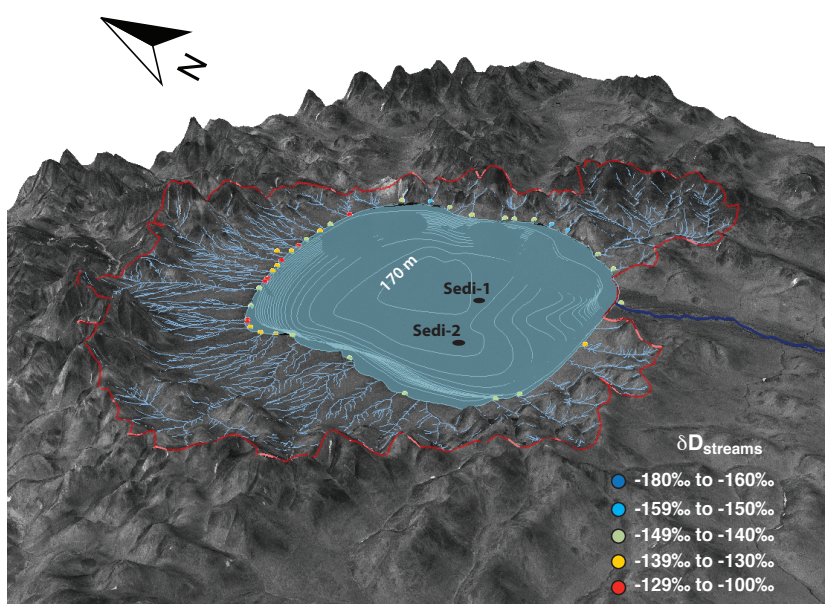

Fig. 2. Location of the sediment traps deployed in Lake El'gygytgyn in 2003, streams and the $\delta \mathrm{D}$ of sampled stream water. View to the $\mathrm{NE}$ with $5 \mathrm{x}$ vertical exaggeration. Coloured dots indicate measured $\delta \mathrm{D}$ of stream waters collected in summer 2003. Red line denotes watershed; streams are indicated in light blue lines. Contours indicate lake bathymetry.

analysis. These samples represent modern sedimentation in the lake.

\subsection{Analytical methods}

\subsubsection{Water isotopic analysis}

The oxygen and hydrogen isotopic compositions of the water samples were analyzed at the Alfred Wegener Institute for Polar and Marine Research (AWI) Potsdam, Germany, with a Finnigan MAT Delta-S mass spectrometer equipped with two equilibration units for online determination following the methods of Meyer et al. (2000). The stable isotope ratios $r_{\mathrm{O}}={ }^{18} \mathrm{O} /{ }^{16} \mathrm{O}$ and $r_{\mathrm{H}}=\mathrm{D} /{ }^{1} \mathrm{H}$ are measured for both sample and reference, and the final ${ }^{18} \mathrm{O}$ and $\delta \mathrm{D}$ values are calculated relative to Vienna Standard Mean Ocean Water (VSMOW) in permil (Gonfiantini, 1978):

$\delta=\frac{r_{\text {sample }}-r_{\text {VSMOW }}}{r_{\text {VSMOW }}}$.

The water samples show an analytical precision $<0.10 \%$ o $(1 \sigma)$ for $\delta^{18} \mathrm{O}$ and $<0.8 \%$ for $\delta \mathrm{D}$, respectively (Meyer et al., 2000).

\subsubsection{Compound-specific isotopic analysis (CSIA)}

The method for vegetation, sediment traps and all sediment samples is identical. Samples were freeze-dried, crushed and stored in combusted glassware. Soluble organic matter was extracted using an accelerated solvent extractor (ASE200, Dionex Corp., Sunnyvale, USA) with a dichloromethane/methanol mixture $(9: 1)$ at $100^{\circ} \mathrm{C}$ and $1200 \mathrm{psi}$ for three $15-\mathrm{min}$ cycles. Given the relatively low amount of organic $\mathrm{C}$ in the samples (Melles et al., unpublished data), the maximum amount of sediment available was used (between $\sim 7 \mathrm{~g}-12 \mathrm{~g}$ dry sediment). The total lipid extract (TLE) was separated into neutral and carboxylic acid fractions on a solid phase extraction (SPE) column containing $0.5 \mathrm{~g}$ of DSC-NH 2 stationary phase (Supelco). A neutral fraction was eluted with $4 \mathrm{ml}$ hexane : DCM $(1: 1)$ and archived for future analysis. Fatty acids were eluted with $8 \mathrm{ml}$ of $2 \%$ formic acid in DCM and were subsequently derivatized as methyl esters (FAME) with $\mathrm{BF}_{3} \mathrm{MeOH}$. Compounds (i.e., FAMES) were identified and quantified using a Hewlett Packard 6890 series gas chromatograph-mass selective detector (GC-MSD) and a Hewlett Packard 6890 series gas chromatograph-flame ionization detector (GC-FID), respectively, and with comparisons to external standard mixtures. Both the GC-MSD and GC-FID were equipped with $5 \%$ phenyl methyl siloxane columns $(30 \mathrm{~m} \times 0.25 \mathrm{~mm}$ ID, film thickness $0.25 \mu \mathrm{m}$ ). The $\mathrm{GC}$ oven temperature programs were also identical for both instruments: $60^{\circ} \mathrm{C}$ ( $\left.2 \mathrm{~min}\right)$, $15^{\circ} \mathrm{C} \mathrm{min}^{-1}$ to $315^{\circ} \mathrm{C}(15 \mathrm{~min})$ with helium as the carrier gas and the inlet temperature set at $320^{\circ} \mathrm{C}$.

The $\delta \mathrm{D}$ of individual lipids was determined at the ESCSIS facility at Yale University using a Thermo Finnigan MAT 253 mass spectrometer with a gas chromatograph combustion 
(GCC) interface with a high-temperature pyrolysis furnace operated at $1440^{\circ} \mathrm{C}$ (Hilkert et al., 1999) coupled with a Thermo Trace GC GC-MS equipped with a DB-5ms column $(30 \mathrm{~m}$, ID: $0.32 \mathrm{~mm}$, film thickness: $0.5 \mu \mathrm{m}$, Agilent). The gas chromatography (GC) temperature program was $80^{\circ} \mathrm{C}(2 \mathrm{~min})$ to $120^{\circ} \mathrm{C}$ at $12^{\circ} \mathrm{C} \mathrm{min}^{-1}$ and then to $320^{\circ} \mathrm{C}$ at $6^{\circ} \mathrm{C} \mathrm{min}^{-1}$ (held $16 \mathrm{~min}$ ). For $\delta \mathrm{D}$ analysis, each sample was analysed in triplicate and the $\mathrm{H}_{3}^{+}$factor was determined daily prior to standard calibration and sample analysis. The results are reported using standard delta notation (i.e., $\delta \mathrm{D}$ values) in permil (\%o) units. Isotope ratios were normalized relative to a co-injected standard mixture containing $\mathrm{C}_{14} n$ alkane $\left(\delta \mathrm{D}_{14 n}\right.$-alkane $\left.=-71.7 \% \circ \pm 1.4 \% \circ\right)$ to condition the furnace and $\mathrm{C}_{15}\left(\delta \mathrm{D}_{15} n\right.$-alkane $=-88.4 \% \circ \pm 1.2 \%$ o $)$ and $\mathrm{C}_{38}$ $n$-alkanes $\left(\delta \mathrm{D}_{14} n\right.$-alkane $\left.=-102.6 \% \circ \pm 1.3 \% \circ\right)$ as compounds of known isotopic values (whose $\delta \mathrm{D}$ values were determined by Arndt Schimmelman, Indiana University, via offline pyrolysis and dual inlet analysis). Instrument performance was also determined daily by measuring a suite of 5 FAMEs with a co-injected standard mixture $\left(n \mathrm{C}_{14}, n \mathrm{C}_{15}, n \mathrm{C}_{38}\right)$ of known isotopic values. The mean precision for replicate analyses of the standard compounds was typically better than $5 \%(1 \sigma)$.

\subsection{Data handling}

\subsubsection{Isotope mass balance correction}

Fatty acid $\delta \mathrm{D}$ values were measured on methyl ester derivatives. A $n$ - $\mathrm{C}_{14}$ acid standard was derivatized with $\mathrm{BF}_{3} \mathrm{MeOH}$ (same lot number as used with samples) to calculate the $\delta \mathrm{D}$ contribution from the three $\mathrm{H}$ atoms added during the methylation reaction with $\mathrm{BF}_{3}$ in $\mathrm{MeOH}$. The bulk $\delta \mathrm{D}$ of this $n-\mathrm{C}_{14}$ fatty acid standard $(-240 \% \circ \pm 2 \% \circ ; n=5)$ was determined prior to derivatization offline by Thermal Conversion Elemental Analysis (TCEA, ESCSIS Yale University). Derivatized standard was measured in triplicate to yield an average $\delta \mathrm{D}$ value for the methyl contribution from the derivitization agent $(-172 \% \circ \pm 3 \%$ ). This value was used to correct the measured $\delta \mathrm{D}$ values of fatty acid methyl esters for the added hydrogen atoms by mass balance.

\subsubsection{Calculation of net "apparent" fractionations}

Isotopic fractionations between two measured substrates, $\delta \mathrm{D}_{\mathrm{a}}$ and $\delta \mathrm{D}_{\mathrm{b}}$, are reported as enrichment factors. Enrichment factors are reported in permil notation, implying a factor of 1000 (Cohen et al., 2007). Here we present the "net (or apparent) fractionation" $\left(\varepsilon_{1 / \mathrm{w}}\right)$ between the $\delta \mathrm{D}$ of leaf wax $\left(\delta \mathrm{D}_{\mathrm{wax}}\right)$ and the $\delta \mathrm{D}$ of source water $\left(\delta \mathrm{D}_{\mathrm{w}}\right)$, commonly used in the plant leaf wax literature, where

$\varepsilon_{\mathrm{wax} / \mathrm{w}}=(\alpha)_{\mathrm{wax} / \mathrm{w}}-1=\frac{\delta \mathrm{D}_{\mathrm{wax}}+1}{\delta \mathrm{D}_{\mathrm{w}}+1}-1$.

Although $\varepsilon_{\mathrm{wax} / \mathrm{w}}$ is typically calculated relative to $\delta \mathrm{D}$ of mean annual precipitation, this inherently assumes that the isotopic composition of the source water $\left(\delta \mathrm{D}_{\mathrm{w}}\right)$ is identical to local $\delta \mathrm{D}$ values of precipitation $\left(\delta \mathrm{D}_{\mathrm{p}}\right)$. In this study, the water available for plant uptake is largely spring snowmelt carried in streams and draining through the shallow active layer (see Sect. 4.1; Nolan, 2012). Therefore, we used the empirically determined average $\delta \mathrm{D}$ for stream inflow. We also calculate the net fractionation between plant leaf wax and annual average precipitation in the basin $\left(\varepsilon_{\text {wax/precip }}\right)$ for comparison.

\subsubsection{Model parameters}

In order to assess the sensitivity of the lake basin to changes in the lake water residence time and changing $\delta \mathrm{D}_{\mathrm{p}}$ and $\delta^{18} \mathrm{O}_{\mathrm{p}}$ over time, we constructed an isotope mass balance model of the lake (Fig. 3):

$\delta_{\text {lake }(i+t)}=\delta_{\text {lake }(i)}+\left(\frac{\delta_{\text {in }(i)}-\delta_{\text {lake }(i)}}{\tau}\right) \cdot \Delta t$

where $\delta_{\text {lake }(i)}$ represents the initial $\delta$ value of the lake water, $\delta_{\text {in }}$ the isotopic composition of input or precipitation, $\tau$ and $t$ the lake residence time and time step (here defined as 1 due to the annual resolution of the tree-ring time series), respectively. Initial lake conditions were assigned based on the present-day mean $\delta \mathrm{D}_{\text {lake }}(-155 \%$ ) and are similar to reconstructed input approximations. As long-term records of past $\delta \mathrm{D}_{\mathrm{p}}$ are lacking in this region, we used $\delta^{18} \mathrm{O}$ data from tree ring cellulose in northern Siberia (Sidorova et al., 2008) to reconstruct the isotopic ratios of past precipitation for input to our model. In order to derive isotope ratios of precipitation from $\delta^{18} \mathrm{O}_{\text {cellulose }}$, we used the relationship between source water (here assumed to be precipitation) and $\delta^{18} \mathrm{O}_{\text {cellulose }}$ described in Anderson et al. (2002). We assigned a midrange value of 0.6 for the fraction of leaf water not subject to evaporation $(f)$ (e.g., Saurer et al., 1997) and a relative humidity $(h)$ of $78 \%$. Average relative humidity was determined from the automated weather station data collected at Lake El'gygytgyn 2002-2008 (Nolan, 2012). Conversion of $\delta^{18} \mathrm{O}_{\text {reconstructed precip }}$ to our proxy model input, $\delta \mathrm{D}_{\text {in }}$, where $\delta \mathrm{D}_{\mathrm{p}} \approx \delta \mathrm{D}_{\text {in }}$, was accomplished by applying our local meteoric water line (LMWL) equation established below (see Sect. $\left.4.1 ; \delta \mathrm{D}=7.35 \delta^{18} \mathrm{O}-9.6\right)$.

\section{Results}

\section{1 $\delta \mathrm{D}$ and $\delta^{18} \mathrm{O}$ values of water samples}

Precipitation collected in summer 2003 (rain), winter 2008/2009 (snow), streams, lake ice and lake water profile samples were analysed for their oxygen and hydrogen isotopic compositions (Fig. 4). Mean $\delta^{18} \mathrm{O}$ and $\delta \mathrm{D}$ values for the different hydrological components are overall lower than previously reported values for the El'gygytgyn Basin (Table 1; Schwamborn et al., 2006). Snow sample $\delta^{18} \mathrm{O}$ values ranged from $-33.92 \%$ o to $-14.10 \%$ (mean: $-23.16 \%$ ) and $\delta \mathrm{D}$ 


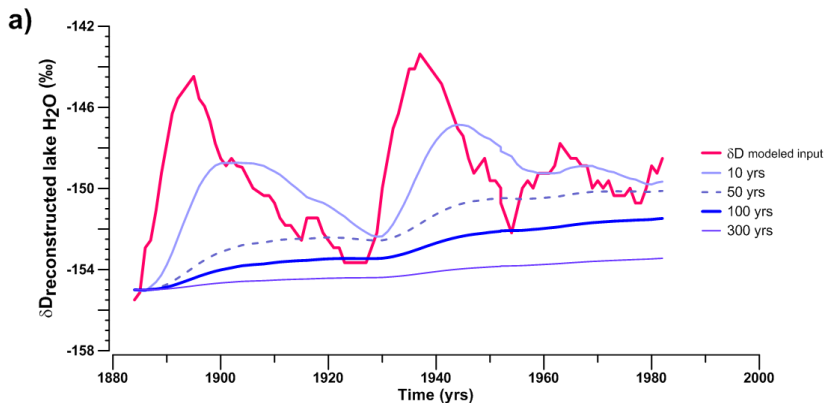

b)

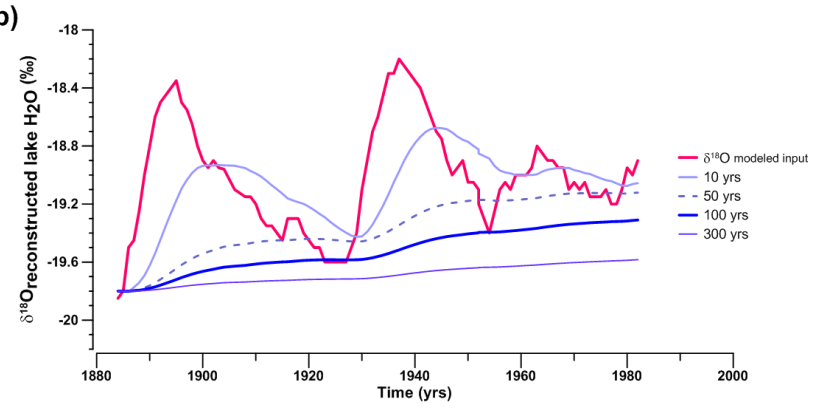

Fig. 3. Isotopic response of the lake water to changes in residence time and variable $\delta \mathrm{D}_{\mathrm{p}}$ of input (precipitation). Pink lines denotes reconstructed (a) $\delta \mathrm{D}$ and (b) $\delta^{18} \mathrm{O}$ of precipitation from $\delta^{18} \mathrm{O}_{\text {cellulose }}$ (Sidorova et al., 2008) based on Anderson et al. (2002). Blue curves show modelled response of $\delta \mathrm{D}_{\text {lake }}$ and $\delta{ }^{18} \mathrm{O}_{\text {lake }}$ with various residence times $(10,50,100$ and $300 \mathrm{yr})$.

values from $-271.0 \%$ to $-100.5 \%$ (mean: $-179.9 \%$ ) (Table 1). Rain $\delta^{18} \mathrm{O}$ values range from $-15.91 \%$ o to $-12.37 \%$ o (mean $-14.29 \%$ ), and $\delta \mathrm{D}$ values range from $-127.5 \%$ to $-98.1 \%$ (mean $-114.8 \%$ ) (Table 1). Summer precipitation shows much lower deuterium excess (d-excess) values (mean d-excess $=-0.5 \%$ ) than winter precipitation and is offset from the global meteoric water line (GMWL) consistent with observations by Schwamborn et al. (2006). The mean d-excess values for both snow and stream samples (5.4\%o and $6.7 \%$ respectively) are similar while lake water d-excess values are lower. Annual average precipitation is calculated partitioning precipitation into a $60 \%$ winter contribution and $40 \%$ summer input (annual average $\delta^{18} \mathrm{O}=-19.61 \%$ o, $\delta \mathrm{D}=-153.9 \%$ ) based on Nolan and Brigham-Grette (2007). These proportions are derived from measurements of water equivalency made in a single year but are thought to be representative for modern climate (Nolan and Brigham-Grette, 2007).

The $\delta \mathrm{D}-\delta^{18} \mathrm{O}$ relationship in winter precipitation samples from the El'gygytgyn Basin closely follows the global meteoric water line (GMWL; Craig, 1961) and defines a linear relationship of

$$
\begin{aligned}
\delta \mathrm{D} & =7.35( \pm 0.24) \delta 180-9.62( \pm 5.64) \\
n & =35 ; R^{2}=0.97
\end{aligned}
$$

where $n$ is the number of data points and $R^{2}$ is the coefficient of determination (Fig. 4). Streams, lake ice and

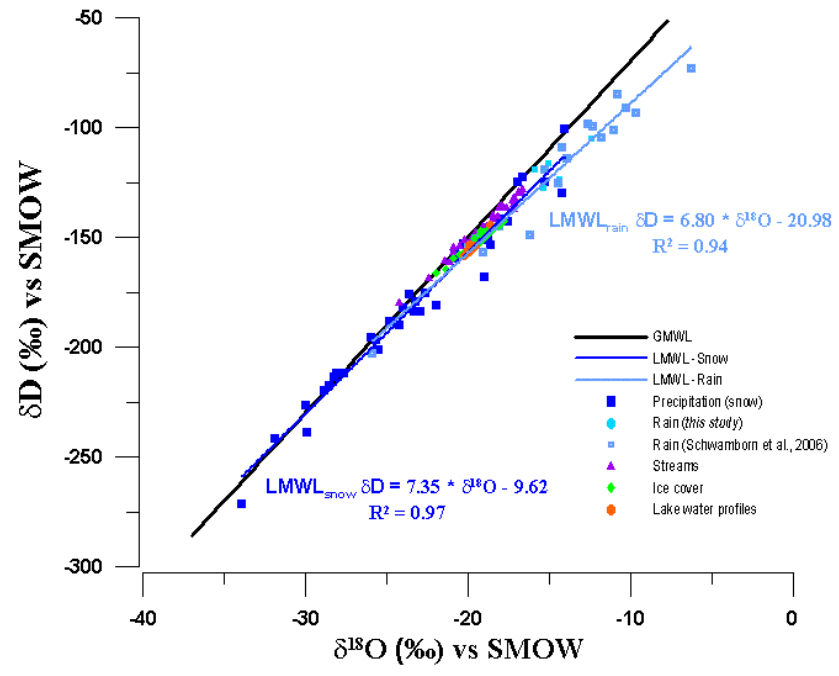

Fig. 4. ${ }^{18} \mathrm{O} / \mathrm{D}$ bi-plot of $\mathrm{H}_{2} \mathrm{O}$ samples from modern precipitation (snow, rain), streams, lake water profiles, surface waters, and ice cover.

lake water profile samples also display similar linear relationships, close to the GMWL and consistent with a circum-polar regression complied from the International Atomic Energy Agency/World Meteorological Organization (IAEA/WMO) Global Network of Isotopes in Precipitation (GNIP) database $\left(\delta \mathrm{D}=7.26 \delta^{18} \mathrm{O}-5.98 ; R^{2}=0.99\right.$; Lacelle, 2011; IAEA/WMO, 2006). Summer precipitation defines a local MWL (LMWL) different from the GMWL $\left(\delta \mathrm{D}=6.80 \delta^{18} \mathrm{O}-22.3 ; R^{2}=0.95\right)$ indicating kinetic fractionation (Fig. 4). These results are consistent with previous observations within the El'gygytgyn Basin (Schwamborn et al., 2006) and in northern Siberia (Meyer et al., 2002; Sugimoto et al., 2003; Kurita et al., 2004; Opel et al., 2011).

The isotopic compositions of precipitation and temperature are strongly correlated at mid- and high latitudes (Dansgaard, 1964), occurring because the degree of rain-out from the atmosphere through condensation is highly correlated with the condensation temperature (see Jouzel et al., 1997 for review). Figure 5 shows the $\delta \mathrm{D}-T$ and $\delta^{18} \mathrm{O}-T$ relationships for the El'gygytgyn Basin for both winter and summer precipitation $(n=26)$. Positive spatial relationships $\left(\delta^{18} \mathrm{O}=\right.$ $\left.0.43 T-18.5, R^{2}=0.68 ; \delta \mathrm{D}=3.1 T-143.7, R^{2}=0.64\right)$ are observed between the isotopic compositions of precipitation and air temperature. Temperatures used are "precipitation temperature" (i.e., surface air temperature during a precipitation event) as isotopic values are discrete events, not weighted means. The slope coefficients of the $\delta-T$ relationships presented here are similar to the spatial $\delta^{18} \mathrm{O}-$ mean air temperature (MAT) relation for Taymyr and Lena data $\left(\delta^{18} \mathrm{O}=0.59\right.$ MAT $-11.47, R^{2}=0.91$; Boike et al., 1997) and data from 47 European IAEA/WMO stations to the west $\left(\delta^{18} \mathrm{O}=0.59\right.$ MAT -14.35 ; Rozanski et al., 1992). However, the slope coefficient for $\delta \mathrm{D}-T$ relationship at 


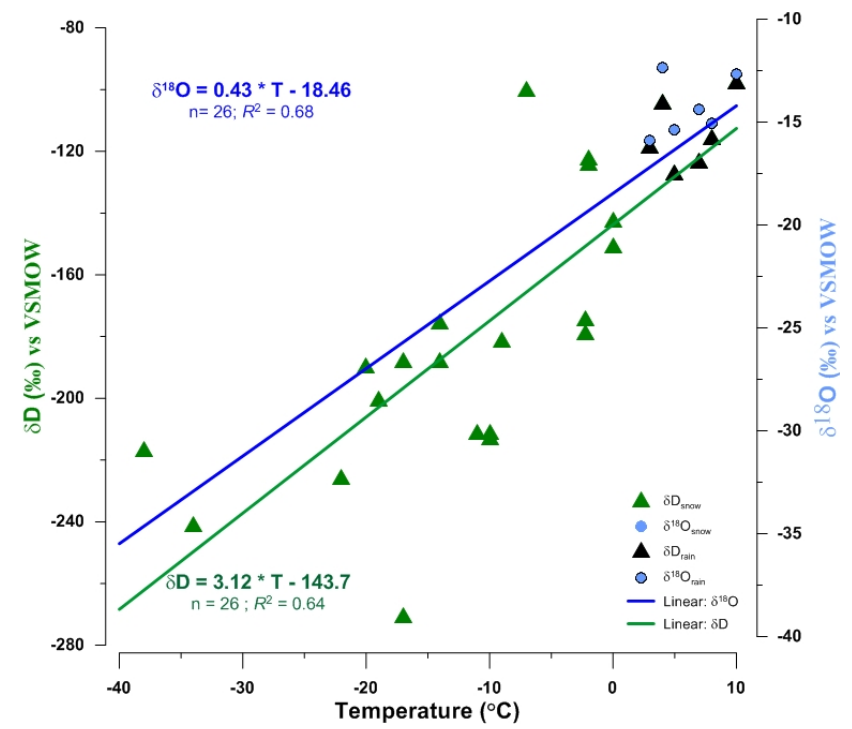

Fig. 5. Relationship between $\delta^{18} \mathrm{O}$ and $\delta \mathrm{D}$ of precipitation with temperature within the El'gygytgyn Basin.

El'gygytgyn is lower than previously reported by Rozanski et al. (1992) $\left(4.5 \% 0^{\circ} \mathrm{C}^{-1}\right)$ and from the Siberian Network of Isotopes in Precipitation $\left(\delta \mathrm{D}_{\text {winter }}=5.6 T_{\mathrm{DJF}}-77.9\right.$; $R^{2}=0.93 ; \delta \mathrm{D}_{\text {summer }}=5.1 T_{\mathrm{JJA}}-157.3 ; R^{2}=0.55$; Kurita et al., 2004).

Spatial variations in the isotopic composition of stream water samples were observed. Stream $\delta^{18} \mathrm{O}$ values ranged from $-24.23 \%$ o to $-16.68 \%$ o (mean $-18.88 \%$ ), and $\delta \mathrm{D}$ values ranged from $-179.5 \%$ to $-127.8 \%$ o (mean $-144.7 \%$; Table 1). Relatively isotopically enriched values cluster predominantly along the south facing and western slopes (Fig. 2). Most negative $\delta^{18} \mathrm{O}$ values and $\delta \mathrm{D}$ values were found along the eastern side of the crater, in streams with relatively high topographic gradients (Fig. 2). Decreasing $\delta^{18} \mathrm{O}$ and $\delta \mathrm{D}$ values broadly correlate with higher relief $\left(R^{2}=\right.$ 0.44 ), with the exception of the shortest stream (Stream 37). There is a general trend toward increasing $\delta^{18} \mathrm{O}$ and $\delta \mathrm{D}$ values over the course of the summer sampling interval $\left(R^{2}=0.33\right)$.

Sampled profiles of the lake water show small $\left(\delta^{18} \mathrm{O}\right.$ : $\sim 1.5 \%$, Chapligin et al., 2012; $\delta \mathrm{D}: \sim 11 \%$, Table 4 ) seasonal variations in the upper $2 \mathrm{~m}$ surface waters. These variations are likely due to spring (May) input from streams carrying isotopically depleted snowmelt and evaporative enrichment during summer (August) (Chapligin et al., 2012). Below $2 \mathrm{~m}$ water depth, the lake is well mixed with an average $\delta \mathrm{D}$ value of $-155.1 \pm 0.3 \%$ o $\left(\delta^{18} \mathrm{O}:-19.82 \%\right.$; Chapligin et al., 2012).

\subsection{Modern vegetation samples}

We report abundances and hydrogen isotope ratios for $\mathrm{C}_{20}$, $\mathrm{C}_{24}, \mathrm{C}_{26}, \mathrm{C}_{28}$, and $\mathrm{C}_{30} n$-alkanoic acids from representa- tive samples of modern vegetation from within the Lake El'gygytgyn Basin (Fig. 6). Despite the small sample set $(n=7)$, we observe a large interspecies variation in the distribution of compounds with some species producing relatively high concentrations of short-chain compounds typically associated with aquatic organisms (i.e., $n \mathrm{C}_{20}$ and $n \mathrm{C}_{22}$ acids; Cranwell et al., 1987; Ficken et al., 2000). The average chain length $\left(\mathrm{ACL}=\sum\left(\mathrm{C}_{n} \cdot n\right) / \sum \mathrm{C}_{n}\right.$, where $n=20,22$, $24,26,28,30)$ for modern vegetation varied between species, ranging from 24 to 27 (Table 2). Concentrations are normalized per $\mathrm{g}$ of total lipid extract (TLE). The highest concentrations of $\mathrm{C}_{30} n$-alkanoic acid were found in the Douglasia ochotensis and Rumex sp. samples, whereas lowest concentrations were observed in Artemisia and Bryophyta sp. High concentrations of $n \mathrm{C}_{28}$ acid were found in the Bryophyta sp., but concentrations of all other $n$-alkanoic acids in the Bryophyta sp. were very low or below detection limit.

For all plants yielding measurable $n$-alkanoic acids, $\delta \mathrm{D}$ values are reported in Table 3. We observe differences in $n$ alkanoic acid chain length abundances for different species as well as isotopic offsets between different chain lengths in some species. Thus, a mass-weighted mean leaf wax $\delta \mathrm{D}$ value $\left(\delta \mathrm{D}_{\text {wax }}\right)$ was calculated to provide a common basis for comparison of the $\delta \mathrm{D}$ of different species regardless of chain length abundances (Table 3). Within El'gygytgyn lake sediments, only $n \mathrm{C}_{30}$ acid can be attributed solely to a terrestrial source (Holland et al., 2012). Therefore, we also compared $\delta \mathrm{D}_{\text {wax }}$ values with the $\delta \mathrm{D}$ values of $n \mathrm{C}_{30}$ acid (i.e., $\delta \mathrm{D}_{30}$ ). The hydrogen isotope compositions of $\mathrm{C}_{30} n$-alkanoic acid $\left(\delta \mathrm{D}_{30}\right)$ strongly correlate with the concentration-weighted $\delta \mathrm{D}_{\text {wax }}$ values $\left(r^{2}=0.97\right)$ confirming $\delta \mathrm{D}_{30}$ values are representative of integrated $\delta \mathrm{D}$ values for terrestrial leaf waxes from plants within the Lake El'gygytgyn watershed (ranging between $-227 \%$ and $-260 \%$ ). Epsilon values between $\delta \mathrm{D}_{\text {wax }}$ and stream water $\left(\varepsilon_{\mathrm{wax} / \text { streams }}\right)$ and $\delta \mathrm{D}_{\text {wax }}$ and annual average precipitation mean $\left(\varepsilon_{\mathrm{wax} / \text { precip }}\right)$ were calculated and are similar to net fractionations calculated solely with $n \mathrm{C}_{30}$-acid (stream water: $\varepsilon_{30 / \text { streams }}$ and annual average

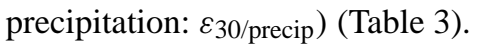

\subsection{Sediment traps and lake sediments}

Concentrations of even chain $n$-alkanoic acids $\left(n \mathrm{C}_{20}, \mathrm{C}_{22}\right.$, $\mathrm{C}_{24}, \mathrm{C}_{26}, \mathrm{C}_{28}$, and $\mathrm{C}_{30}$ ) varied widely between sediment traps and samples of the upper $0-2 \mathrm{~cm}$ of lake sediments (Fig. 7). Sediment traps show variable distributions of compounds and concentrations with water depth with highest concentrations of all compounds at $90 \mathrm{~m}$ water depth (Fig. 7). Individual compounds were normalized by total yield of $n$ alkanoic acids to show changes in the relative proportions of compounds (normalized to total yield of $n$-alkanoic acids) with water depth (Fig. 8). The upper surface waters show high percentages of $\mathrm{C}_{20}, \mathrm{C}_{22}, \mathrm{C}_{24}$, and $\mathrm{C}_{26}$ acids with a marked decline of $\mathrm{C}_{22}$ acid by $50 \mathrm{~m}$ depth. The shortest chain $n$-alkanoic acid, $n \mathrm{C}_{20}$, decreases with depth. Below 


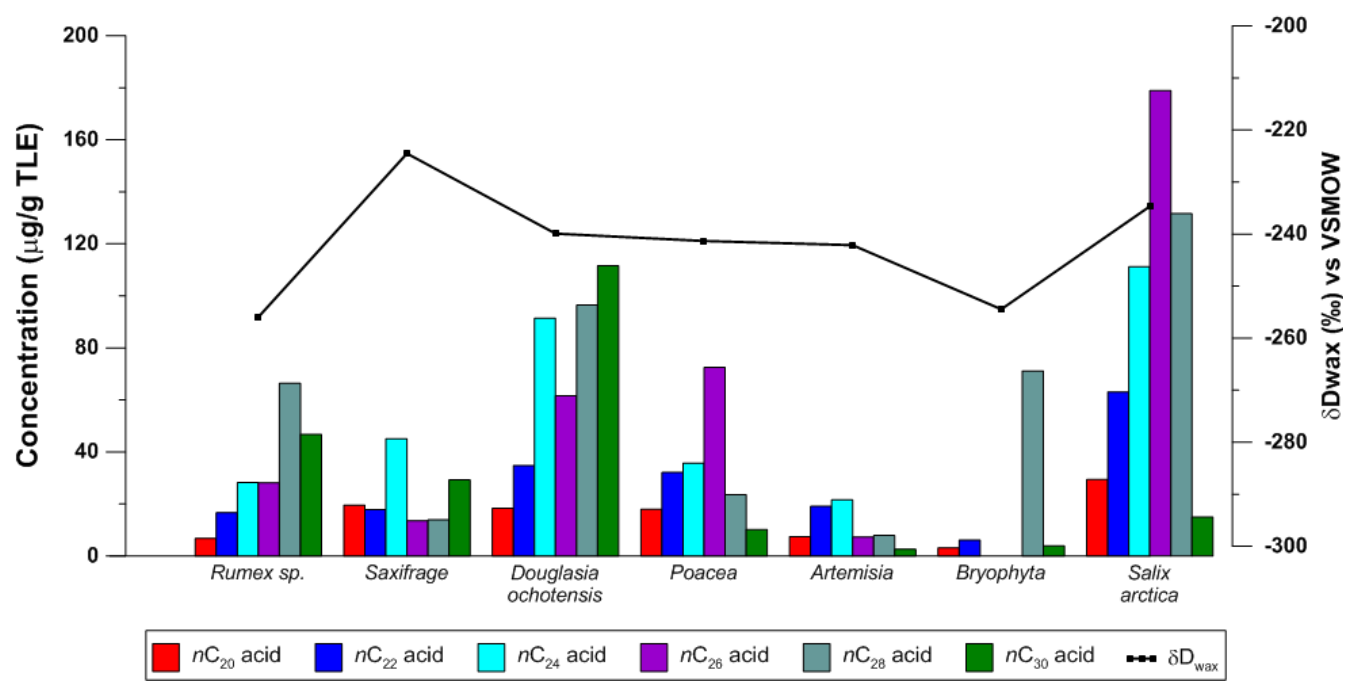

Fig. 6. Concentrations and $\delta \mathrm{D}$ values of $n$-alkanoic acids measured in modern vegetation samples from within the El'gygytgyn Basin.

Table 2. Concentrations of selected $n$-alkanoic acids from vegetation, sediment traps from various water depths, and lake bottom sediment from various depths with the El'gygytgyn Basin.

\begin{tabular}{|c|c|c|c|c|c|c|c|}
\hline \multirow[b]{2}{*}{ Sample } & \multicolumn{6}{|c|}{ Concentration ( $\left.\mu \mathrm{gg}^{-1} \mathrm{TLE}\right)$} & \multirow[b]{2}{*}{ ACL* } \\
\hline & $\mathrm{C}_{20}$ & $\mathrm{C}_{22}$ & $\mathrm{C}_{24}$ & $\mathrm{C}_{26}$ & $\mathrm{C}_{28}$ & $\mathrm{C}_{30}$ & \\
\hline Rumex sp. & 6.7 & 16.6 & 28.2 & 28.1 & 66.4 & 46.8 & 27 \\
\hline Saxifrage & 19.6 & 17.8 & 45.1 & 13.6 & 13.9 & 29.2 & 25 \\
\hline D. ochotensis & 18.4 & 34.8 & 91.4 & 61.6 & 96.4 & 111.6 & 26 \\
\hline Poaceae & 18.0 & 32.1 & 35.7 & 72.5 & 23.6 & 10.2 & 25 \\
\hline Artemisia & 7.5 & 19.1 & 21.6 & 7.3 & 7.9 & 2.6 & 24 \\
\hline Bryophyta & 3.2 & 6.1 & & & 71.2 & 3.9 & 27 \\
\hline Salix arctica & 29.4 & 63.1 & 111.2 & 178.9 & 131.6 & 15.0 & 25 \\
\hline Sediment trap $(30 \mathrm{~m})$ & 14.3 & 20.6 & 21.4 & 15.4 & 7.9 & 7.2 & 24 \\
\hline Sediment trap $(50 \mathrm{~m})$ & 8.2 & 8.7 & 10.2 & 8.1 & 4.3 & 5.6 & 24 \\
\hline Sediment trap $(90 \mathrm{~m})$ & 23.5 & 41.9 & 30.3 & 25.5 & 12.7 & 25.8 & 24 \\
\hline Sediment trap (130 m) & & 6.0 & 7.7 & 4.7 & 3.5 & 4.2 & 25 \\
\hline Sediment trap $(146 \mathrm{~m})$ & & 1.1 & 1.6 & 1.2 & 0.6 & 0.7 & 25 \\
\hline Sediment core top $(159 \mathrm{~m})$ & 12.2 & 39.2 & 78.3 & 72.5 & 68.4 & 21.1 & 25 \\
\hline Sediment core top $(168 \mathrm{~m})$ & 136.6 & 412.0 & 818.3 & 776.6 & 626.8 & 230.1 & 25 \\
\hline Sediment core top $(170 \mathrm{~m})$ & 1341 & 4273 & 9016 & 8819 & 7488 & 2660 & 25 \\
\hline
\end{tabular}

$* \mathrm{ACL}=$ average chain length as defined in text.

$50 \mathrm{~m}, \mathrm{C}_{30}$ and $\mathrm{C}_{22}$ acids appear to co-vary, whereas $\mathrm{C}_{24}, \mathrm{C}_{26}$, and $\mathrm{C}_{28}$ follow a similar general trend down to $130 \mathrm{~m}$ water depth. Concentrations of $\mathrm{C}_{24}$ and $\mathrm{C}_{26}$ increase at the deepest sediment trap ( $146 \mathrm{~m}$ water depth), yielding higher percentages of these compounds near the lake bottom than in surface waters. Abundances of all compounds in all sediment traps were too low for $\delta \mathrm{D}$ analysis.

High concentrations of all compounds were observed in the upper $0-2 \mathrm{~cm}$ of lake sediments, increasing in concentrations with increasing lake water depth (note log scale, Fig. 7). The distribution of all compounds is consistent across all samples as indicated by calculated values of average chain length (ACL; Table 2). The hydrogen isotope compositions of sedimentary $n$-alkanoic acids are also reasonably consistent across samples (i.e., sedimentary $\delta \mathrm{D}_{30}$ values varied by $\sim 10 \%$; within $2 \sigma$ analytical error). Net fractionation values calculated between terrestrially sourced sedimentary $n \mathrm{C}_{30}$ acid and different source waters (stream water; $\varepsilon_{30 / \text { streams }}$ or

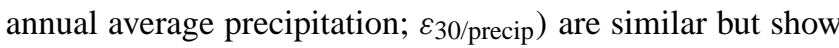
slightly greater fractionation between $n \mathrm{C}_{30}$ acid and stream water $\left(\right.$ mean $\varepsilon_{30 / \text { streams }}=-114 \pm 13 \%$; mean $\varepsilon_{30 / \text { precip }}=$ $-105 \pm 13 \%$; Table 3 ). 


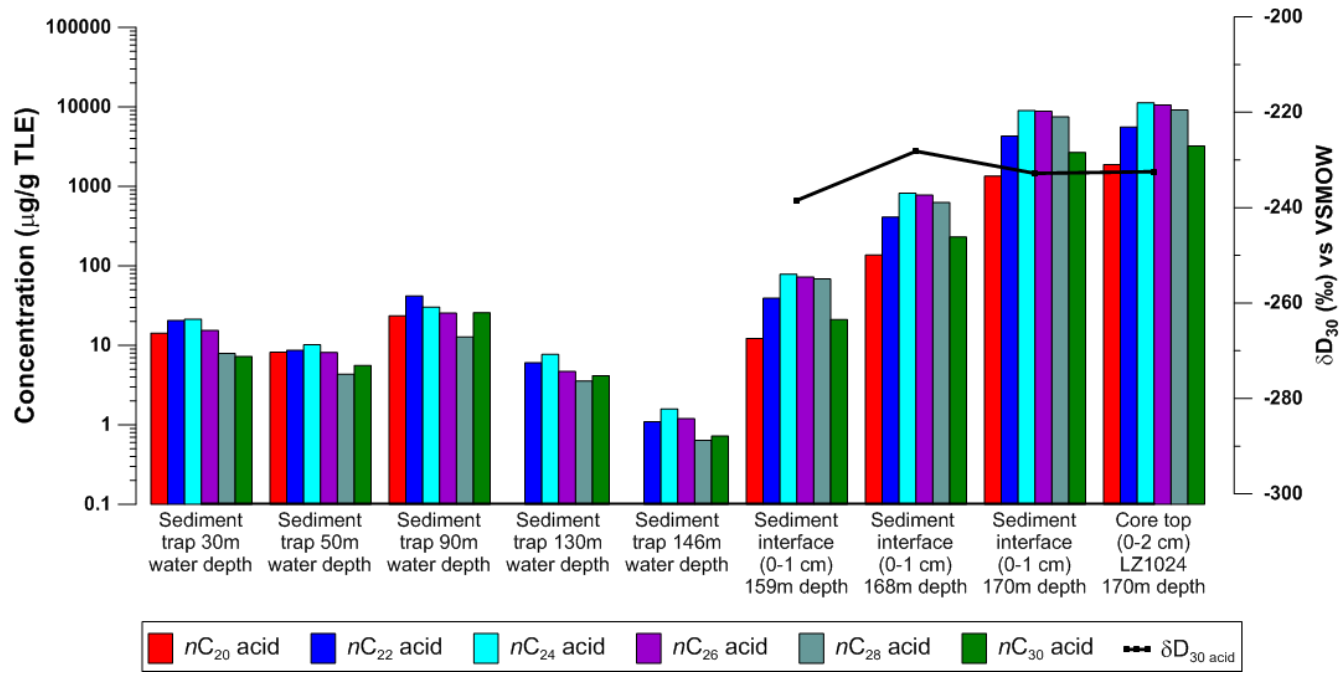

Fig. 7. Concentrations of $n$-alkanoic acids with water column depth in sediment traps and lake surface sediments (note log scale). $\delta \mathrm{D}_{\text {wax }}$ values are plotted for lake surface sediments only as concentrations of $n$-alkanoic acids in sediment traps were insufficient for compoundspecific $\delta \mathrm{D}$ analysis.

Table 3. $\delta \mathrm{D}$ values for selected $n$-alkanoic acids from vegetation, sediment traps from various water depths, and lake bottom sediment from various depths with the El'gygytgyn Basin.

\begin{tabular}{|c|c|c|c|c|c|c|c|c|c|c|c|c|c|c|c|c|c|}
\hline \multirow[b]{2}{*}{ Sample } & \multirow[b]{2}{*}{$\delta \mathrm{D}_{20}$} & \multirow[b]{2}{*}{ SD } & \multirow[b]{2}{*}{$\delta \mathrm{D}_{22}$} & \multirow[b]{2}{*}{ SD } & \multirow[b]{2}{*}{$\delta \mathrm{D}_{24}$} & \multirow[b]{2}{*}{ SD } & \multirow[b]{2}{*}{$\delta \mathrm{D}_{26}$} & \multirow[b]{2}{*}{ SD } & \multirow[b]{2}{*}{$\delta \mathrm{D}_{28}$} & \multirow[b]{2}{*}{ SD } & \multirow[b]{2}{*}{$\delta \mathrm{D}_{30}$} & \multirow[b]{2}{*}{ SD } & \multirow[b]{2}{*}{$\delta \mathrm{D}_{\mathrm{wax}}^{\mathrm{b}}$} & \multicolumn{2}{|c|}{$\varepsilon_{\mathrm{C} 30 / \mathrm{w}}$} & \multicolumn{2}{|c|}{$\varepsilon_{\mathrm{wax} / \mathrm{w}}$} \\
\hline & & & & & & & & & & & & & & $\begin{array}{r}\varepsilon_{30 /} \\
\text { streams }\end{array}$ & $\begin{array}{r}\varepsilon_{30 /} \\
\text { precip }\end{array}$ & $\begin{array}{r}\mathcal{E}_{\mathrm{wax} /} \\
\text { streams }\end{array}$ & $\begin{array}{c}\varepsilon_{\text {wax/ }} \\
\text { precip }\end{array}$ \\
\hline Rumex sp. & -247 & 5 & -263 & 1 & -259 & 1 & -263 & 1 & -262 & 2 & -259 & 1 & -260 & -134 & -126 & -135 & -127 \\
\hline D. ochotensis & -245 & 4 & -234 & 1 & -242 & 6 & -243 & 2 & -249 & 1 & -244 & 2 & -244 & -116 & -107 & -116 & -107 \\
\hline Poaceae & & & -237 & 6 & -236 & 4 & -256 & 3 & -239 & 6 & & & -245 & & & -118 & -109 \\
\hline Artemisia & -225 & 5 & -246 & 1 & -249 & 2 & -253 & 1 & -257 & 1 & -242 & 2 & -247 & -114 & -105 & -119 & -111 \\
\hline Average & & & & & & & & & & & -242 & & -244 & -114 & -105 & -116 & -107 \\
\hline \multicolumn{18}{|l|}{ Sediment trap $(30 \mathrm{~m})$} \\
\hline \multicolumn{18}{|l|}{ Sediment trap (50 m) } \\
\hline \multicolumn{18}{|l|}{ Sediment trap $(90 \mathrm{~m})$} \\
\hline \multirow{2}{*}{\multicolumn{18}{|c|}{$\begin{array}{l}\text { Sediment trap }(130 \mathrm{~m}) \\
\text { Sediment trap }(146 \mathrm{~m})\end{array}$}} \\
\hline Sediment trap $(146 \mathrm{~m})$ & & & & & & & & & & & & & & & & & \\
\hline Average & & & & & & & & & & & -233 & & -236 & -103 & -95 & -107 & -98 \\
\hline
\end{tabular}

a $\delta \mathrm{D}_{\text {wax }}=$ mean mass weighted $\delta \mathrm{D}$ leaf wax $=\sum\left([\mathrm{Cn}\right.$ acid $\left.] * \delta \mathrm{D}_{\mathrm{n}}\right) / \sum([\mathrm{Cn}$ acid $])$

\section{Discussion}

\subsection{Modern isotope hydrology}

The isotopic composition of modern precipitation and various components of the hydrological system provide the basis for applying paleoclimatic interpretations to stable isotope compositions of sediment archives (Schwamborn et al., 2006). Here we outline the modern isotope hydrology from precipitation to stream runoff to lake water and discuss the major controls on each component. Each of these components affects the hydrogen isotope composition ultimately recorded in the $\delta \mathrm{D}$ values from leaf wax lipids.

Precipitation regimes are influenced by air temperature, proximity to moisture sources and air mass trajectories over landmasses. Consequently, the $\delta^{18} \mathrm{O}$ and $\delta \mathrm{D}$ values in local precipitation (i.e., $\delta \mathrm{D}_{\mathrm{p}}$ ) are highly variable and the slope values of local meteoric precipitation often deviate from the GMWL. Spatially, lower slope values are located in areas with local orographic effects and continental climatic 
Table 4. $\delta^{18} \mathrm{O}$ and $\delta \mathrm{D}$ values of lake water from Lake El'gygytgyn at various depths (May and August, 2003; November 2008).

\begin{tabular}{lrrrrr}
\hline & $\begin{array}{r}\text { water } \\
\text { depth [m] }\end{array}$ & $\begin{array}{r}\delta^{18} \text { O }(\%) \\
\text { vs. SMOW }\end{array}$ & $\begin{array}{r}\text { SD } \\
(1 \sigma)\end{array}$ & $\begin{array}{l}\delta \text { Ds }(\% o) \\
\text { vaOW }\end{array}$ & $\begin{array}{r}\text { SD } \\
(1 \sigma)\end{array}$ \\
\hline 14 November 2008 & 1 & -19.84 & 0.02 & -155.8 & 0.3 \\
14 November 2008 & 5 & -19.78 & 0.03 & -155.5 & 0.2 \\
14 November 2008 & 10 & -19.76 & 0.04 & -155.0 & 0.4 \\
14 November 2008 & 20 & -19.77 & 0.03 & -154.8 & 0.2 \\
14 November 2008 & 40 & -19.75 & 0.02 & -154.8 & 0.1 \\
14 November 2008 & 60 & -19.73 & 0.04 & -155.5 & 0.4 \\
14 November 2008 & 80 & -19.75 & 0.02 & -155.3 & 0.4 \\
14 November 2008 & 100 & -19.77 & 0.05 & -154.5 & 0.4 \\
14 November 2008 & 120 & -19.76 & 0.02 & -154.4 & 0.2 \\
14 November 2008 & 160 & -19.81 & 0.02 & -154.5 & 0.2 \\
27 May 2003 & 2 & -20.21 & 0.05 & -158.2 & 0.4 \\
27 May 2003 & 10 & -19.95 & 0.00 & -155.7 & 0.0 \\
27 May 2003 & 30 & -19.99 & 0.04 & -156.2 & 0.0 \\
27 May 2003 & 50 & -19.84 & 0.00 & -155.8 & 0.0 \\
27 May 2003 & 100 & -19.85 & 0.02 & -155.5 & 0.1 \\
27 May 2003 & 150 & -19.95 & 0.01 & -155.7 & 0.3 \\
27 May 2003 & 165 & -19.92 & 0.00 & -156.2 & 0.4 \\
27 May 2003 & 168 & -19.85 & 0.01 & -155.4 & 0.1 \\
2 August 2003 & 2 & -18.65 & 0.02 & -144.5 & 0.2 \\
2 August 2003 & 10 & -19.76 & 0.01 & -154.3 & 0.2 \\
2 August 2003 & 30 & -19.73 & 0.01 & -154.0 & 0.1 \\
2 August 2003 & 50 & -19.55 & 0.00 & -154.1 & 0.1 \\
2 August 2003 & 100 & -19.76 & 0.04 & -154.6 & 0.4 \\
2 August 2003 & 150 & -19.80 & 0.01 & -155.5 & 0.7 \\
2 August 2003 & 165 & -19.72 & 0.01 & -154.3 & 0.1 \\
2 August 2003 & 168 & -19.82 & 0.02 & -154.5 & 0.1 \\
3 August 2003 & 2 & -19.91 & 0.00 & -156.4 & 0.3 \\
3 August 2003 & 10 & -19.87 & 0.02 & -155.2 & 0.2 \\
3 August 2003 & 30 & -19.94 & 0.03 & -156.1 & 0.3 \\
3 August 2003 & 50 & -19.93 & 0.03 & -153.4 & 0.6 \\
3 August 2003 & 100 & -19.89 & 0.01 & -155.9 & 0.4 \\
3 August 2003 & 150 & -19.90 & 0.02 & -155.5 & 0.3 \\
3 August 2003 & 165 & -19.85 & 0.01 & -155.5 & 0.5 \\
3 August 2003 & 168 & -19.88 & 0.01 & -156.1 & 0.4 \\
\hline & & & & & \\
\hline
\end{tabular}

regimes, while higher slope values are from sites with maritime climates (Lacelle, 2011). East Siberian Arctic winter precipitation exhibits a wide range of stable isotopic compositions (e.g., Kurita et al., 2004), and although the values presented here are not weighted means, the range of variation (e.g., $\Delta \delta^{18} \mathrm{O}$ values $=17 \%$ and $\Delta \delta \mathrm{D}$ values $=19 \%$ ) is similar to that previously reported within the El'gygytgyn Basin (Schwamborn et al., 2006). Modern winter precipitation at Lake El'gygytgyn closely follows the $\delta \mathrm{D}$ and $\delta^{18} \mathrm{O}$ values of precipitation from other Arctic sites in the GNIP database. The values of the slope (7.35) and the y-intercept $(-9.62)$ are lower than the GMWL but very close to the GNIP-based circum-polar regression, indicating a nearly unaltered precipitation signal from the original moisture source during winter months. In contrast, summer precipitation shows a clear kinetic fractionation of isotopes with lower slope and d-excess values. This may be related to enhanced evaporation occurring during summer months in typical tundra settings due to the water surplus on the land surface and continuous 24-h net radiation (Ohmura, 1982; Boike, 1997, 1998). Reprecipitated moisture derived from recycled water masses from the land surface may also be included (Sugimoto et al., 2003; Kurita et al., 2004; Schwamborn et al., 2006).

The seasonal contrast in modern precipitation may also be explained by the strong seasonality in the dominant weather patterns. Modern synoptic weather patterns identified from National Centers for Environmental Prediction (NCEP) global reanalysis data show strong low pressure systems over the Aleutians during winter and broad high pressure systems to the south and east with weaker lows to the north during the summer (Nolan et al., 2012). Strong Aleutian lows during winter tend to bring cold Arctic air from the 


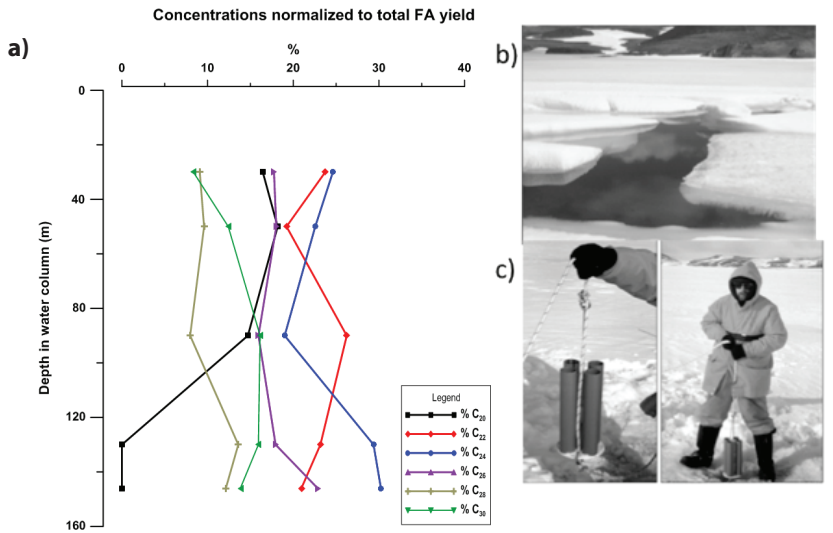

Fig. 8. (a) Concentrations of $n$-alkanoic acids normalized to total yield of $n$-alkanoic acids by water column depth in Lake El'gygytgyn. (b) Large moat formed by ice melt $500 \mathrm{~m}$ to the north of the southern shore on 17 June 2003 - approximately 1/3 way through sediment trap deployment (from Melles et al., 2005). Note extent of snow and lake ice cover during typical summer month. (c) Sediment traps deployed 31 May 2003 and recovered 19 July 2003 (from Melles et al., 2005).

east and north to the lake, whereas summer synoptic weather patterns bring warm continental air from the south and west (Nolan et al., 2012). Thus, these dominant weather patterns affect both the seasonal temperature change and source of moisture delivery to Lake El'gygytgyn. Seasonal air temperature changes affect the saturation vapour pressure of air masses and subsequently the degree of rainout, yielding decreasing precipitation isotope ratios with decreasing temperatures and along trajectories of atmospheric vapour transport. These trajectories deliver winter precipitation from a proximal north and eastern moisture source (i.e., E. Siberian, Chukchi and Bering seas and possibly North Pacific) and recycled moisture from the Siberian land surface from the south and west during the summer months. High d-excess values of winter precipitation in the El'gygytgyn Basin support a proximal moisture source with minimal alteration of the original isotopic composition while low d-excess values during summer months are consistent with recycled continental moisture from the south and west. Furthermore, Nolan et al. (2012) suggest that these weather patterns have been relatively stable with time and are likely representative of this and other interglacial periods.

Input to the lake via streams draining from the crater rim is predominantly driven by winter snowmelt and shows spatial variations in isotopic composition according to stream gradient and slope aspect (Fig. 2). Stream samples are more ${ }^{18} \mathrm{O}$ and $\mathrm{D}$ depleted than overall summer precipitation isotope ratios with values closer to mean annual precipitation $\left(\delta \mathrm{D}_{\mathrm{p}}\right)$. This suggests that stream waters carry a large winter precipitation signal offset by some input of isotopically enriched summer precipitation and/or evaporative enrichment of the soil water. Water tracks, characteristic of per- mafrost terrain and immature drainage systems, are common on El'gygytgyn slopes with rapid drainage of moisture through the active layer in early spring/ summer (Nolan and Brigham-Grette, 2007; Federov et al., 2012). The residence time of the water in the soil typically produces a dampening of the seasonal variations observed in precipitation (Buhay and Edwards, 1995; Anderson et al., 2002). However, this residence time is exceedingly short within the El'gygytgyn Basin. Therefore, stream water effectively represents the soil moisture in the basin, draining rapidly and recharged annually by snowmelt. Soil moisture data collected from different depths within the El'gygytgyn Basin (to base of active layer; 2002-2008) show peak soil moisture in early spring prior to peak soil temperatures and with individual summer precipitation events having only a minor effect on soil moisture content (Federov et al., 2012). Deep permafrost in this region ( $500 \mathrm{~m}$; Yershov, 1998; Schwamborn et al., 2006) precludes deep groundwater input, and streams are therefore representative of soil moisture recharged by winter precipitation draining through the shallow active layer during the short summer season.

Streams with south facing and western slopes display relatively enriched isotope compositions. Lower gradients for these slopes, longer transit times and seasonally greater net incoming solar radiation likely resulted in ${ }^{18} \mathrm{O}$ and $\mathrm{D}$ enrichment of these stream waters due to evaporation. These streams were also sampled late in the summer season, well after peak discharge and when flow in many of the smaller streams was reduced $\left(<1 \mathrm{~m}^{3} \mathrm{~s}^{-1}\right)$ and is often just a trickle (Nolan and Brigham-Grette, 2007). Thus, despite summer sampling during maximum expected evaporative enrichment, the isotopic ratios of stream samples appear biased towards more negative winter precipitation isotope ratios though offset by some minor evaporative enrichment.

Small seasonal changes are also observable in the isotopic composition of the lake water. Profiles of the lake water column show seasonal enrichment of the surface waters in summer and depleted surface waters in early spring. Although thermally stratified in winter due to ice cover, the lake is rapidly mixed following snowmelt and ice breakup in late May (Nolan and Brigham-Grette, 2007) with little variation below the uppermost surface waters. Isotopically depleted lake surface waters ( $2 \mathrm{~m}$ depth, Table 4 ) collected in late May are likely the combined result of melting lake surface snow and ice and input from streams carrying isotopically depleted snowmelt. Evaporative enrichment of the lake surface waters in summer (August) is small and likely very brief given vertical mixing due to strong winds (Nolan and Brigham-Grette, 2007) and has little to no influence on the overall isotopic composition of the lake (Chapligin et al., 2012).

The mean hydrogen isotope composition of the lake water $\left(\delta \mathrm{D}_{\text {lake }}\right)$ is largely controlled by the hydrogen isotope composition of precipitation $\left(\delta \mathrm{D}_{\mathrm{p}}\right)$, duration of ice cover and the residence time of the lake. Input to the lake is a combination of direct precipitation on the lake surface and stream 
discharge. Streams account for $85 \%$ of water input to the lake (Fedorov et al., 2012), and prolonged or perennial ice cover prevents evaporative enrichment of surface waters. Accordingly, the average isotopic ratio of modern lake water is slightly more depleted in ${ }^{18} \mathrm{O}$ and $\mathrm{D}$ when compared to mean annual precipitation values, reflecting either greater input from isotopically depleted snowmelt and/or a lag in response based on lake residence time to past changes in $\delta \mathrm{D}_{\mathrm{p}}$.

To assess the impact of this potential lag, lake water isotopic response was modelled by isotope mass balance (Fig. 3). Variations in $\delta D_{p}$ are reflected in the lake water isotopic response within decades ( $\geq 10 \mathrm{yr}$ ), but the magnitude of the response is strongly attenuated by the residence time. Modern residence times for Lake El'gygytgyn are $\sim 120 \mathrm{yr}$ (Federov et al., 2009, 2012) but could have been greater during ice-covered, glacial conditions. Although the modelled $\delta \mathrm{D}_{\text {lake }}$ does not record the full magnitude of minor fluctuations of $\delta \mathrm{D}_{\mathrm{p}}$, these results suggest $\delta \mathrm{D}_{\text {lake }}$ does still respond to large magnitude changes in input on long glacial-interglacial timescales (see also Chapligin et al., 2012).

\subsection{Climate signal preserved in plant leaf waxes}

\subsubsection{Modern vegetation}

Modern vegetation within the El'gygytgyn Basin produced a range of $n$-alkanoic acids with variable concentrations and $\delta \mathrm{D}$ values. Reconstructions of the $\delta \mathrm{D}$ of meteoric water rely on a constant "net fractionation" between lipid and meteoric water. Differences between plant species and vegetation type may affect the net fractionation (e.g., Chikaraishi and Naraoka, 2003; Smith and Freeman 2006; Hou et al., 2007b). However, within watersheds these differences are integrated and a representative multi-species net fractionation factor may be appropriate for paleohydrologic reconstructions (Feakins and Sessions, 2010). Modern vegetation within the El'gygytgyn Basin includes 249 identified plant species and approximately an additional 100 rare species (Kohzenikov, 1993; Minyuk, 2005).

In order to evaluate how representative the seven sampled species are of all vegetation within the basin, we calculated an unweighted average distribution of compounds (Fig. 9). This unweighted average was then used to produce a representative assemblage of $n$-alkanoic acids within the El'gygytgyn Basin (Fig. 9). This modern vegetation distribution pattern was then compared with an average distribution of compounds from modern sediments calculated from all four sediment core tops. The two patterns are similar, although, as expected, there are discrepancies given the relatively small sample set and the modern floristic diversity within the basin. The modern vegetation distribution pattern appears particularly sensitive to Bryophyta weighting. Reducing the contribution from Bryophyta from the overall modern vegetation pattern results in a distribution similar to that observed in modern lake sediments. This may be be-

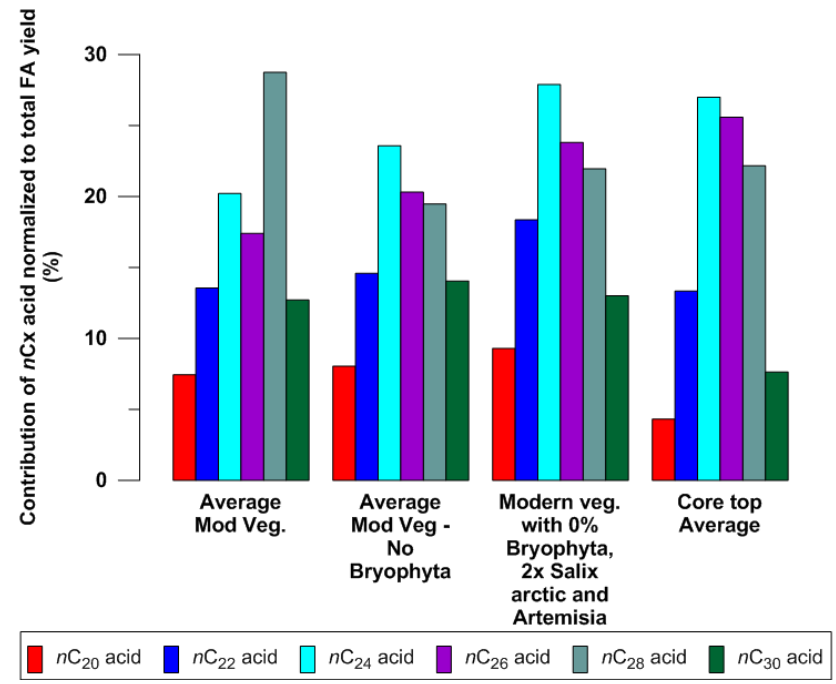

Fig. 9. Average distribution of $n$-alkanoic acids from modern vegetation within the El'gygytgyn Basin (far left) and in core top sediments (far right). Modelled distributions are shown with varying proportions of vegetation species. Compounds are normalized to total yield of $n$-alkanoic acids.

cause Bryophyta may not be a significant portion of overall plant biomass in the basin or alternatively may not be major contributor of terrestrially sourced $n$-alkanoic acids to the lake. Additionally, Salix arctica and Artemisia spp. are abundant on El'gygytgyn slopes and modification of their proportional contributions produces a nearly identical distribution of compounds to modern lake sediments (Fig. 9). Minor differences may certainly be attributed to and accounted for with the further inclusion and proportional representation of the remaining vegetation types and species. This preliminary survey suggests that although the proportional contributions of each species to the overall pattern may change, these six species (excluding Bryophyta) are generally representative of the overall production and input of even-chain $n$-alkanoic acids from modern vegetation to the lake basin.

The hydrogen isotope composition observed in sampled vegetation may also be representative basin-wide. The range of interspecies $\delta \mathrm{D}$ variability observed around Lake El'gygytgyn is within other published ranges (e.g., Chikaraishi and Naraoka, 2003; Liu and Huang, 2005; Sachse et al., 2006; Hou et al., 2007; Feakins and Sessions, 2010), although these authors note that there is significant scatter at the level of individual plants across a wide range of climatic conditions. Some studies have linked $\delta \mathrm{D}$ values to life form (e.g., tree, shrub, and grass; Smith and Freeman, 2006; Liu et al., 2006; Liu and Yang, 2008). However, no clear linkage between $\delta \mathrm{D}$ values and life form was found in our study. Yet, despite a large spread between individuals, catchment scale average $\delta \mathrm{D}_{\text {wax }}$ values generally do seem to reliably record the climate conditions of the region (e.g., Huang et al., 2004; Sachse et al., 2004; Feakins and Sessions, 
2010) thereby allowing for a constant offset to be used for paleoenvironmental reconstructions.

The climate signals preserved in alkanoic acids from modern vegetation within the El'gygytgyn Basin closely reflect the isotopic composition of mean annual precipitation, with a possible bias towards winter precipitation due to the nature of water availability in an arid Arctic context. Within arid Arctic regions, and particularly at this site, snowmelt is the dominant annual hydrological feature (see Sect. 5.1) (Nolan and Brigham-Grette 2007; Federov et al., 2012). Given the presence and depth of extensive permafrost within the basin, this precludes deeper groundwater input and the majority of water available for plant uptake occurs as rapid drainage of snowmelt (i.e., winter precipitation) through the shallow active layer. The short growing season in this region - coinciding with warmer temperatures and enhanced snowmelt also contributes to growth and production of biomass utilizing soil moisture dominated by stream water (active layer runoff) carrying a large winter precipitation signal offset by some input of isotopically enriched summer precipitation. Soil moisture data in this basin also show individual summer precipitation events have only a minor effect on soil moisture content (Federov et al., 2012). Thus, water availability may be the primary mechanism by which the isotopic composition of mean annual precipitation is recorded by the leaf wax proxy in the El'gygytgyn Basin.

Our calculated $\varepsilon_{\mathrm{wax} / \mathrm{w}}$ values (Table 3) display an overall average net fractionation between modern vegetation and stream water $\left(\varepsilon_{\mathrm{wax} / \text { streams }}\right)$ of $-116 \pm 12 \%$. However, this assumes that the source water available for plant uptake is directly represented by streams in the El'gygytgyn Basin (i.e., $\delta_{\mathrm{w}}=\delta_{\text {streams }}$ ). Potential changes in the seasonality of precipitation and Arctic summer productivity (i.e., timing of biosynthesis with respect to peak snowmelt and runoff) suggests caution in application of $\varepsilon_{\mathrm{wax} / \text { streams }}$ in paleohydrological reconstructions. These values could also be affected by inclusion of more plant samples and species given the large range of known $\delta \mathrm{D}$ diversity between individuals (Hou et al., 2007b). Average net fractionation between modern vegetation and annual average precipitation $\left(\varepsilon_{\text {wax }}\right.$ precip $)$ in the El'gygytgyn Basin is slightly more positive $(-107 \pm 12 \%$ ). These values are very similar to average net fractionations of $-99 \pm 8 \%$ reported from a North American transect of $\mathrm{C}_{28} n$-alkanoic acids (Hou et al., 2008) suggesting consistent offset between source waters and the $\delta \mathrm{D}$ values of alkanoic acids.

Net fractionation between long chain $\left(\mathrm{C}_{27}, \mathrm{C}_{29}\right.$ and $\left.\mathrm{C}_{31}\right)$ $n$-alkanes and source water in arid to semi-arid ecosystems also display similar values $(-94 \pm 21 \%$; Feakins and Sessions, 2010) although $n$-alkanoic acids are expected to be enriched in D compared to $n$-alkanes from the same source by about $25 \pm 16 \%$ o based on their biosynthetic origins (Chikaraishi and Naraoka, 2007). A broad trend to less negative net fractionation values between $\mathrm{C}_{29}$ alkanes and mean annual precipitation was found globally for drier regions (characterized by relative humidity $<0.7$ and evapotranspiration $<1000 \mathrm{~mm} \mathrm{yr}^{-1}$; Sachse et al., 2012). Our data suggest that net fractionation values for alkanoic acids may not follow the same trend, but larger global data sets for net fractionations for terrestrial $n$-alkanoic acids are needed.

In a global compilation, Sachse et al. (2012) report significant differences in leaf wax $n$-alkane $\delta \mathrm{D}$ values among different plant life forms. Liu and Yang (2008) report a high latitude effect with smaller $n$-alkane $\varepsilon_{\text {wax/w }}$ values for woody plants versus grasses at high latitudes. Within the El'gygytgyn Basin, Salix and Poaceae comprise the dominant woody and non-woody taxa respectively (Minyuk, 2005; Lozhkin et al., 2007). Grasses (Poaceae), which are dominated by $\mathrm{C}_{3}$ graminoids at this latitude, produce leaf waxes that are more D-depleted relative to source water likely due to physiological differences in leaf architecture as well as in location and timing of wax synthesis (Hou et al., 2007; Sachse et al., 2012). Although limited, our data also show less negative $n$-alkanoic acid $\varepsilon_{\mathrm{wax} / \mathrm{w}}$ values for woody plants versus grasses (Table 3 ). These results suggest that vegetation changes, especially during major climatic shifts, have the potential to affect the overall $\delta \mathrm{D}_{\text {wax }}$ signal in catchment sediments. Thus, additional data from other paleoclimate proxies (e.g., pollen assemblages) should be used in combination with molecular paleohydrological interpretations from $\delta \mathrm{D}$ values of terrestrial $n$-alkanoic acids.

\subsubsection{Sediment traps}

The abundances and distribution of compounds produced by vegetation directly affect the integrated signal captured in lake sediments, and, thus, any sedimentary isotopic signature could be complicated by the inclusion of compounds from multiple sources with differing isotopic composition. Parallel compound-specific $\delta^{13} \mathrm{C}$ analysis shows that, within El'gygytgyn sediments, $n \mathrm{C}_{30}$ acid derives from a strictly terrestrial source while other even long chain $n$-alkanoic acids derive from a mixed terrestrial and aquatic source (Wilkie et al., 2013; Holland et al., 2013). This same study further shows that $n \mathrm{C}_{20}$ and $n \mathrm{C}_{22}$ acids likely derive from an aquatic source. However, production of these compounds in modern vegetation (this study; see above) initially suggests some contribution of a terrestrial source of these compounds to lake sediments. This explicitly requires intact delivery of these terrestrially sourced compounds to the lake bottom. Our results show the abundances of these compounds vary with depth in the water column, suggesting multiple processes in the water column influencing the ultimately integrated signal captured in lake sediments.

Even short chain $n$-alkanoic acids (e.g., $n \mathrm{C}_{14}-n \mathrm{C}_{22}$ ) typically produced by phytoplankton and/or bacteria (Cranwell et al., 1987; Gong and Hollander, 1997) are more labile and subject to rapid turnover in the water column (Lee et al., 2004; Jones et al., 2008). Thus, the observed trend in $n \mathrm{C}_{20}$ acid is consistent with aquatic production in the upper 
surface waters and degradation with depth. Combined terrestrial inputs and aquatic production of even chain $n \mathrm{C}_{20^{-}}$ $\mathrm{C}_{26}$ acids likely contribute a higher proportion of these compounds to surface waters, while the sharp decline by $50 \mathrm{~m}$ depth could reflect early degradation of the more labile shorter chain $n \mathrm{C}_{22}$ acid. Although $n \mathrm{C}_{24}$ and $n \mathrm{C}_{26}$ acids are typically attributed to terrestrial sources, some aquatic production (i.e., subaquatic/floating macrophytes and filamentous algae similar to those observed in El'gygytgyn streams and lagoons) of these mid-chain fatty acids has been reported (Cranwell et al 1987; Ficken et al., 2000).

Relative abundances of $n \mathrm{C}_{24}$ and $n \mathrm{C}_{26}$ acids increase in the deepest water column sample, exceeding values observed in upper surface waters. This suggests either additional input at depth (e.g., delivery of terrestrial material from dense hyperpycnal flows from warming moat and lagoon waters), autochthonous production at intermediate to lower depths in the water column (>90 $\mathrm{m}$ water depth), and/or advantageous capture of sinking organic debris entrained in and subsequently released by melting snow and lake ice. However, delivery of terrestrially sourced $\mathrm{C}_{24}$ and $\mathrm{C}_{26}$ acids by hyperpycnal flows is unlikely as this would also result in a concomitant increase in concentrations and relative proportions of $n \mathrm{C}_{28}$ and $n \mathrm{C}_{30}$ acids. While we cannot rule out autochthonous preferential production of $n \mathrm{C}_{24}$ and $n \mathrm{C}_{26}$ acids below $90 \mathrm{~m}$ water depth, capture of previously ice entrained sinking organic debris seems likely during the period of sediment trap deployment (late May to mid-July). Substantial lake ice persisted for most of the trap deployment, with extensive ice melting, development of leads and moat formation occurring throughout sample collection (Fig. 8). Ice-rafted fatty acids (IRFAs), possibly entrained during the previous fall freeze and accumulated over winter through aeolian deposition on lake snow and ice, would be released to the water column sporadically during lake ice melt and breakup. These settling plumes of IRFAs could explain the increase in total concentrations of all fatty acids at $90 \mathrm{~m}$ water depth, while shifting proportions with depth could reflect variable melt and release times of the ice over the site. The isotopic ratios of these IRFAs would still reflect their original biological sources regardless of transport and ice residence times though the signal from compounds of both aquatic and terrestrial sources would be obscured. Further deployment and study of timeseries sediment traps is required to fully assess modern water column processes and contributions to lake floor sediments.

\subsubsection{Lake sediments}

Lake sediments represent an integrated signal from the watershed, and the carboxylic acids within them typically originate from multiple sources (Meyers, 2003). Concentrations of fatty acids in core top sediments increase exponentially towards the deepest part of the basin consistent with greater accommodation space and lower sediment supply resulting in less dilution of the organic signal. An age model devel- oped on the deepest core from the central part of the lake (LZ1024, $170 \mathrm{~m}$ water depth) yields an age of 200 years for the upper $0-1 \mathrm{~cm}$. This sampling resolution for the lake surface sediments implies that seasonal to interannual variations are lost and the "modern" sediments are an integrated average of climate and deposition for the last $200 \mathrm{yr}$. The consistent distribution of compounds across surface sediment samples regardless of water depth confirms a catchmentintegrated organic signal reaching the lake bottom. Thus, the climatic signal from leaf waxes in lake surface sediments is a combined average for all vegetation changes in the catchment in the last $200 \mathrm{yr}$ (i.e., molecular abundances). Additionally, the sedimentary $\delta \mathrm{D}_{\text {wax }}$ also represents an integrated signal of precipitation for the last $200 \mathrm{yr}$. Longterm $\delta \mathrm{D}_{\mathrm{p}}$ records are lacking at this site. However, the reconstructed estimates of $\delta D_{p}$ from the northern Yakutia $\delta^{18} \mathrm{O}_{\text {cellulose }}$ record (Sidorova et al., 2008) yields a 97-yraverage reconstructed $\delta \mathrm{D}_{\mathrm{p}}$ of approximately $-147 \%$. Net fractionations between core top sediments and either streams $\left(\varepsilon_{\mathrm{C} 30 / \text { streams }}=-103 \pm 5 \%\right.$ or precipitation $\left(\varepsilon_{\mathrm{C} 30 / \text { precip }}=\right.$ $-95 \pm 5 \%$ ) closely agree with $\varepsilon_{\mathrm{wax} / \mathrm{w}}$ values from modern vegetation (streams: $\varepsilon_{\mathrm{wax} / \text { streams }}=-116 \pm 12 \%$; precipitation: $\varepsilon_{\text {wax/precip }}=-107 \pm 12 \%$ o). Calculation of these values inherently applies present-day input to a time-integrated signal, yet recalculation with the derived time-averaged $\delta \mathrm{D}_{\mathrm{p}}$ still yields near identical net fractionation values $(\sim-100 \%)$.

\section{Conclusions}

This study provides a detailed assessment of the stable isotopic composition of modern hydrology within the El'gygytgyn Basin and the controls on the $\delta \mathrm{D}$ signature from plant leaf waxes within the El'gygytgyn Basin. Our results suggest different source regions for winter and summer precipitation, characterized by an unaltered isotopic signature from a northern and eastern moisture source in winter and a south-southwest continental moisture source including recycled moisture from the land surface. LMWL determined within the El'gygytgyn Basin is consistent with other circumpolar regressions (Kurita et al., 2004; Lacelle, 2011), though the local spatial $\delta$ - $T$ relationships are lower than previously reported. However, evaporative enrichment is not a strong control on $\delta \mathrm{D}_{\text {lake }}$ and the lake responds relatively quickly to large magnitude changes in $\delta \mathrm{D}_{\mathrm{p}}$. Changes in the length of the residence time are reflected in the degree of dampening of the $\delta \mathrm{D}_{\mathrm{p}}$-driven signal, with longer residence times averaging out shorter-term (e.g., decadal) changes. Inflow from streams in the basin represents soil wa$\operatorname{ter}\left(\delta_{\text {soil water }} \delta_{\text {streams }}\right)$ that is annually recharged by snowmelt, drained rapidly and relatively unaffected by summer precipitation events. Enhanced evaporative enrichment on southfacing slopes causes $\delta_{\text {streams }}$ to more closely reflect annual average $\delta \mathrm{D}_{\mathrm{p}}$. Plants utilize this water within the active layer so $\delta \mathrm{D}_{\text {wax }}$ should reflect $\delta_{\text {streams. }}$. However, large interspecies 
variability and potential changes in seasonality of precipitation suggest caution in applying $\varepsilon_{\text {wax/streams }}$ in paleohydrological reconstructions. Therefore, it may be more prudent to use $\varepsilon_{\text {wax/precip }}$ for paleohydrological reconstructions. We observed an offset between woody vs. grass samples though given the small sample set here this might be inconclusive. These results suggest that vegetation changes have the potential to affect the overall $\delta \mathrm{D}_{\text {wax }}$ signal in catchment sediments. Larger sample sets including more species and multiple individuals within each genus are needed. In modern lake sediments, $\varepsilon_{\mathrm{C} 30 / \text { precip }}=-95 \pm 5 \%$, which is determined only from terrestrially sourced $n \mathrm{C}_{30}$ acid and represents catchment-wide integrated signal $(200 \mathrm{yr}$ of all basin vegetation and $\left.\delta \mathrm{D}_{\mathrm{p}}\right)$. Utilizing reconstructed $(\sim 100 \mathrm{yr}$ average) $\delta D_{p}$ cellulose to calculate net fractionations for 200 yr-integrated lake sediments yields $\varepsilon_{30 / \text { precip }}=-96 \pm 8 \%$.

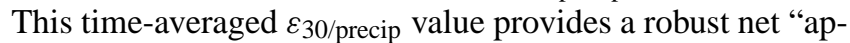
parent" fractionation to be used in future paleohydrological reconstructions.

Acknowledgements. The authors would like to gratefully acknowledge helpful and constructive discussions with all members of the El'gygytgyn Science Team and especially the generous advice and assistance of Marianna Voevodskaya (CRDF, Moscow, Russia). We thank S. Feakins and D. Sachse for their thoughtful comments that helped improve this paper. Funding for this research was provided by the International Continental Scientific Drilling Program (ICDP), the US National Science Foundation (NSF), the German Federal Ministry of Education and Research (BMBF), Alfred Wegener Institute (AWI) and GeoForschungsZentrum Potsdam (GFZ), the Russian Academy of Sciences Far East Branch (RAS FEB), the Russian Foundation for Basic Research (RFBR), and the Austrian Federal Ministry of Science and Research (BMWF).

Edited by: M. Melles

\section{References}

Anderson, W., Bernasconi, S., McKenzie, J., Saurer, M., and Schweingruber, F.: Model evaluation for reconstructing the oxygen isotopic composition in precipitation from tree ring cellulose over the last century, Chem. Geol., 182, 121-137, doi:10.1016/S0009-2541(01)00285-6, 2002.

Boike, J.: Thermal, hydrological and geochemical dynamics of the active layer at the continuous permafrost site, Taymyr Peninsula, Siberia, Ph.D., University of Potsdam, Potsdam, 1997.

Boike, J., Roth, K.. and Overduin, P. P.: Thermal and hydrologic dynamics of the active layer at a continuous permafrost site (Taymyr Peninsula, Siberia), Water Resour. Res., 34, 355-399, doi:10.1029/97WR03498, 1998.

Bowen, G. J. and Revenaugh, J.: Interpolating the isotopic composition of modern meteoric precipitation, Water Resour. Res., 39, 1299-1312, doi:10.1029/2003WR002086, 2003.

Buhay, W. M. and Edwards, T.: Climate in Southwestern Ontario, Canada, between AD 1610 and 1885 Inferred from Oxygen and Hydrogen Isotopic Measurements of Wood Cellulose from Trees in Different Hydrologic Settings, Quaternary Res., 44, 438-446, doi:10.1006/qres.1995.1089, 1995.

Cardoso, J. N., Gaskell, S. J., Quirk, M. M., and Eglinton, G.: Hydrocarbon and fatty acid distributions in Rostherne lake sediment (England), Chem. Geol., 38, 107-128, doi:10.1016/00092541(83)90048-7, 1983.

Castañeda, I. S. and Schouten, S.: A review of molecular organic proxies for examining modern and ancient lacustrine environments, Quaternary Sci. Rev., 30, 2851-2891, doi:10.1016/j.quascirev.2011.07.009, 2011.

Chapligin, B., Meyer, H., Bryan, A., Snyder, J., and Kemnitz, H.: Assessment of purification and contamination correction methods for analysing the oxygen isotope composition from biogenic silica, Chem. Geol., 300-301, 185-199, doi:10.1016/j.chemgeo.2012.01.004, 2012.

Chikaraishi, Y. and Naraoka, H.: Compound-specific $\delta \mathrm{D}-\delta 13 \mathrm{C}$ analyses of n-alkanes extracted from terrestrial and aquatic plants, Phytochemistry, 63, 361-371, doi:10.1016/S00319422(02)00749-5, 2003.

Chikaraishi, Y. and Naraoka, H.: $\delta^{13} \mathrm{C}$ and $\delta \mathrm{D}$ relationships among three n-alkyl compound classes (n-alkanoic acid, n-alkane and n-alkanol) of terrestrial higher plants, Org. Geochem., 38, 198215, doi:10.1016/j.orggeochem.2006.10.003, 2007.

Cohen, E. R., Cvitaš, T., Frey, J. G., Holmström, B., Kuchitsu, K., Marquardt, R., Mills, I., Pavese, F., Quack, M., Stohner, J., Strauss, H. L., Takami, M., and Thor, A. J.: Quantities, Units and Symbols in Physical Chemistry, 3rd Edn., Royal Society of Chemistry Publishing, Cambridge, UK, 2007.

Craig, H.: Isotopic Variations in Meteoric Waters, Science, 133, 1702-1703, doi:10.1126/science.133.3465.1702, 1961.

Craig, H. and Gordon, L. I.: Deuterium and oxygen 18 variations in the ocean and the marine atmosphere, Vol. 337, edited by: Tongiogi, E., 9-130, V. Lishi e F., Pisa, Spoleto, Italy, 1965.

Cranwell, P. A.: Monocarboxylic acids in lake sediments: Indicators, derived from terrestrial and aquatic biota, of paleoenvironmental trophic levels, Chem. Geol., 14, 1-14, doi:10.1016/00092541(74)90092-8, 1974.

Cranwell, P. A., Eglinton, G., and Robinson, N.: Lipids of aquatic organisms as potential contributors to lacustrine sediments-II, Org. Geochem., 11, 513-527, doi:10.1016/01466380(87)90007-6, 1987.

Cremer, H., Wagner, B., Juschus, O., and Melles, M.: A microscopical study of diatom phytoplankton in deep crater Lake El'gygytgyn, Northeast Siberia, Arch. Hydrobiol. Suppl. Algol. Stud., 116, 147-169, doi:10.1127/1864-1318/2005/0116-0147, 2005.

Dansgaard, W.: Stable isotopes in precipitation, Tellus, 16, 436468, doi:10.1111/j.2153-3490.1964.tb00181.x, 1964.

Eglinton, G. and Hamilton, R. J.: Leaf Epicuticular Waxes, Science, 156, 1322-1335, doi:10.1126/science.156.3780.1322, 1967.

Eglinton, T. I. and Eglinton, G.: Molecular proxies for paleoclimatology, Earth Planet. Sci. Lett., 275, 1-16, doi:10.1016/j.eps1.2008.07.012, 2008.

Feakins, S. J. and Sessions, A. L.: Controls on the D/H ratios of plant leaf waxes in an arid ecosystem, Geochim. Cosmochim. Ac., 74, 2128-2141, 2010.

Federov, G., Bolshijanov, D. J., and Schwamborn, G.: Hydroand sedimentological-balanced research from Lake Elgygytgyn, Chukotka, in: The system of the Laptev Sea and adjacent 
Arctic seas current status and history of development, edited by: Kassens, K., Lisitzin, A. P., Thiede, J., Polykova, Y. I., Timokhov, L. A., and Frolov, I. E., p. 9, Moscow University Press, Moscow, Russia, 2009.

Fedorov, G., Nolan, M., Brigham-Grette, J., Bolshiyanov, D., Schwamborn, G., and Juschus, O.: Lake El'gygytgyn water and sediment balance components overview and its implications for the sedimentary record, Clim. Past Discuss., 8, 3977-4001, doi:10.5194/cpd-8-3977-2012, 2012.

Ficken, K. J., Li, B., Swain, D. L., and Eglinton, G.: An nalkane proxy for the sedimentary input of submerged/floating freshwater aquatic macrophytes, Org. Geochem., 31, 745-749, doi:10.1016/S0146-6380(00)00081-4, 2000.

Gat, J. R.: Oxygen and Hydrogen Isotopes in the Hydrologic Cycle, Annu. Rev. Earth Planet. Sci., 24, 225-262, doi:10.1146/annurev.earth.24.1.225, 1996.

Glushkova, O. Y. and Smirnov, V. N.: Pliocene to Holocene geomorphic evolution and paleogeography of the El'gygytgyn Lake region, NE Russia, J. Paleolimnol., 37, 37-47, doi:10.1007/s10933-006-9021-x, 2006.

Gonfiantini, R.: Environmental isotopes in lake studies. In: Handbook of Environmental Isotope Geochemistry, The Terrestrial Environment B, Vol. II., edited by: Fritz, P. and Fontes, J. Ch., Elsevier, Amsterdam, 113-168, 1986.

Gonfiantini, R.: Standards for stable isotope measurements in natural compounds, Nature, 271, 534-536, doi:10.1038/271534a0, 1978.

Gong, C. and Hollander, D. J.: Differential contribution of bacteria to sedimentary organic matter in oxic and anoxic environments, Santa Monica Basin, California, Org. Geochem., 26, 545-563, doi:10.1016/S0146-6380(97)00018-1, 1997.

Hilkert, A. W., Douthitt, C. B., Schlüter, H. J., and Brand, W. A.: Isotope ratio monitoring gas chromatography/Mass spectrometry of $\mathrm{D} / \mathrm{H}$ by high temperature conversion isotope ratio mass spectrometry, Rapid Commun. Mass Sp., 13, 1226-1230, 1999.

Holland, A. R., Petsch, S. T., Castañeda, I. S., Wilkie, K. M., Burns, S. J., and Brigham-Grette, J.: A biomarker record of Lake El'gygytgyn, Far East Russian Arctic: investigating sources of organic matter and carbon cycling during marine isotope stages 1-3, Clim. Past, 9, 243-260, doi:10.5194/cp-9-243-2013, 2013.

Hou, J., D'Andrea, W. J., MacDonald, D., and Huang, Y.: Evidence for water use efficiency as an important factor in determining the delta D values of tree leaf waxes, Org. Geochem., 38, 12511255, doi:10.1016/J.Orggeochem.2007.03.011, 2007a.

Hou, J., D'Andrea, W. J., Macdonald, D., and Huang, Y.: Hydrogen isotopic variability in leaf waxes among terrestrial and aquatic plants around Blood Pond, Massachusetts (USA), Org. Geochem., 38, 977-984, doi:10.1016/j.orggeochem.2006.12.009, 2007b.

Hou, J., D’Andrea, W. J., and Huang, Y.: Can sedimentary leaf waxes record $\mathrm{D} / \mathrm{H}$ ratios of continental precipitation? Field, model, and experimental assessments, Geochim. Cosmochim. Ac., 72, 3503-3517, doi:10.1016/j.gca.2008.04.030, 2008.

Huang, Y., Shuman, B., Wang, Y., and Webb, T.: Hydrogen isotope ratios of palmitic acid in lacustrine sediments record late Quaternary climate variations, Geology, 30, 1103-1106, 2002.

Huang, Y., Shuman, B., Wang, Y., and Webb, T.: Hydrogen isotope ratios of individual lipids in lake sediments as novel tracers of climatic and environmental change: a surface sediment test, J.
Paleolimnol., 31, 363-375, 2004.

Jacob, J., Huang, Y., Disnar, J. R., Sifeddine, A., Boussafir, M., Spadano Albuquerque, A. L., and Turcq, B.: Paleohydrological changes during the last deglaciation in Northern Brazil, Quaternary Sci. Rev., 26, 1004-1015, 2007.

Jones, A. A., Sessions, A. L., Campbell, B. J., Li, C., and Valentine, D. L.: D/H ratios of fatty acids from marine particulate organic matter in the California Borderland Basins, Org. Geochem., 39, 485-500, 2008.

Jouzel, J., Alley, R. B., Cuffey, K. M., Dansgaard, W., Grootes, P., Hoffmann, G., Johnsen, S. J., Koster, R. D., Peel, D., Shuman, C. A., Stievenard, M., Stuiver, M., and White, J.: Validity of the Temperature Reconstruction from Water Isotopes in Ice Cores, J. Geophys. Res., 102, 26471-26487, 1997.

Juschus, O., Brigham-Grette, J., Wennrich, V., Quart, S., and Wennrich, R.: Hydrological Field Measurements and Water Sampling, edited by: Melles, M., Minyuk, P. S., Brigham-Grette, J., and Juschus, O., The expedition El'gygytgyn Lake 2003 (Siberian Arctic), 509, 30-35, 2005a.

Juschus, O., Melles, M., Wennrich, V., Quart, S., and Dehnert, A.: Particles settling through the water column, edited by: Melles, M., Minyuk, P. S., Brigham-Grette, J., and Juschus, O., Ber. Polar-und Meerforsh., 509, 30-35, 2005b.

Kane, D. J., Hinzman, L. D., Ming-ko, W., and Everett, K. R.: Arctic hydrology and climate change, in: Arctic ecosystems in a changing climate?: an ecophysiological perspective, edited by: Chapin, F. S., Jefferies, R. L., Reynolds, J. F., Shaver, G. R., and Svoboda, J., 35-57, Academic Press, San Diego, 1992.

Kohzevnikov, Yu. P.: Vascular plants in the vicinities of the Elgygytgyn Lake, in: The Nature of the El'gygytgyn Lake Hollow, edited by: Bely, V. F. and Chereshnev, I. A., NEISRI FEB RAS Magadan, 62-82, 1993 (in Russian).

Kurita, N., Yoshida, N., Inoue, G., and Chayanova, E. A.: Modern isotope climatology of Russia: A first assessment, J. Geophys. Res., 109, D03102, doi:10.1029/2003JD003404, 2004.

Lacelle, D.: On the $\delta 18 \mathrm{O}, \delta \mathrm{D}$ and D-excess relations in meteoric precipitation and during equilibrium freezing: theoretical approach and field examples, Permafrost Periglac., 22, 13-25, 2011.

Layer, P. W.: Argon - 40/argon - 39 age of the El'gygytgyn impact event, Chukotka, Russia, Meteorit. Planet. Sci, 35, 591-599, doi:10.1111/j.1945-5100.2000.tb01439.x, 2000.

Leaney, F. W., Osmond, C. B., Allison, G. B., and Ziegler, H.: Hydrogen-isotope composition of leaf water in $\mathrm{C}_{3}$ and $\mathrm{C}_{4}$ plants: its relationship to the hydrogen-isotope composition of dry matter, Planta, 164, 215-220, doi:10.1007/BF00396084, 1985.

Lee, C., Wakeham, S., and Arnosti, C.: Particulate Organic Matter in the Sea: The Composition Conundrum, AMBIO: A Journal of the Human Environment, 33, 565-575, 2004.

Leng, M. J. and Marshall, J. D.: Palaeoclimate interpretation of stable isotope data from lake sediment archives, Quaternary Sci. Rev., 23, 811-831, 2004.

Liu, W. and Huang, Y.: Compound specific D/H ratios and molecular distributions of higher plant leaf waxes as novel paleoenvironmental indicators in the Chinese Loess Plateau, Org. Geochem., 36, 851-860, doi:10.1016/j.orggeochem.2005.01.006, 2005.

Liu, W. and Yang, H.: Multiple controls for the variability of hydrogen isotopic compositions in higher plant n-alkanes from modern ecosystems, Global Change Biol., 14, 2166-2177, 
doi:10.1111/j.1365-2486.2008.01608.x, 2008.

Liu, W., Yang, H., and Li, L.: Hydrogen isotopic compositions of nalkanes from terrestrial plants correlate with their ecological life forms, Oecologia, 150, 330-338, doi:10.1007/s00442-006-0494$0,2006$.

Lozhkin, A. V., Anderson, P. M., Matrosova, T. V., and Minyuk, P. S.: The pollen record from El'gygytgyn Lake: implications for vegetation and climate histories of northern Chukotka since the late middle Pleistocene, J. Paleolimnol., 37, 135-153, doi:10.1007/s10933-006-9018-5, 2006.

Melles, M., Minyuk, P. S., Brigham-Grette, J., and Juschus, O.: The expedition El'gygytgyn Lake 2003 (Siberian Arctic), AlfredWegener-Institut für Polar- und Meeresforschung, Bremerhaven, 145 p. 2005.

Meyer, H., Schönicke, L., Wand, U., Hubberten, H. W., and Friedrichsen, H.: Isotope Studies of Hydrogen and Oxygen in Ground Ice - Experiences with the Equilibration Technique, Isot. Environm. Healt. S., 36, 133-149, doi:10.1080/10256010008032939, 2000.

Meyer, H., Dereviagin, A., Siegert, C., Schirrmeister, L., and Hubberten, H.-W.: Palaeoclimate reconstruction on Big Lyakhovsky Island, North Siberia-Hydrogen and oxygen isotopes in ice wedges, Permafrost Periglac., 13, 91-105, doi:10.1002/ppp.416, 2002.

Meyers, P. A.: Applications of organic geochemistry to paleolimnological reconstructions: a summary of examples from the Laurentian Great Lakes, Org. Geochem., 34, 261-289, doi:10.1016/S0146-6380(02)00168-7, 2003.

Meyers, P. A. and Ishiwatari, R.: Lacustrine organic geochemistry - an overview of indicators of organic matter sources and diagenesis in lake sediments, Org. Geochem., 20, 867-900, doi:10.1016/0146-6380(93)90100-P, 1993.

Minyuk, P. S.: Vegetation around Lake El'gygytgyn, in: The expedition El'gygytgyn Lake 2003 (Siberian Arctic), vol. 509, edited by: Melles, M., Minyuk, P. S., Brigham-Grette, J., and Juschus, O., 30-35, 2005.

Nolan, M.: Analysis of local AWS and NCEP/NCAR reanalysis data at Lake El'gygtytgyn, and its implications for maintaining multi-year lake-ice covers, Clim. Past Discuss., 8, 1443-1483, doi:10.5194/cpd-8-1443-2012, 2012.

Nolan, M. and Brigham-Grette, J.: Basic hydrology, limnology, and meteorology of modern Lake El'gygytgyn, Siberia, J. Paleolimnol., 37, 17-35, doi:10.1007/s10933-006-9020-y, 2007.

Nolan, M., Cassano, E., and Cassano, J.: Synoptic climatology and recent climate trends at Lake El'gygytgyn, Clim. Past Discuss., 8, 1485-1522, doi:10.5194/cpd-8-1485-2012, 2012.

Ohmura, A.: Climate and energy balance on the arctic tundra, J. Climatol., 2, 65-84, doi:10.1002/joc.3370020106, 1982.

Opel, T., Dereviagin, A. Y., Meyer, H., Schirrmeister, L., and Wetterich, S.: Palaeoclimatic information from stable water isotopes of Holocene ice wedges on the Dmitrii Laptev Strait, northeast Siberia, Russia, Permafrost Periglac., 22, 84-100, doi:10.1002/ppp.667, 2011.

Polissar, P. J. and Freeman, K. H.: Effects of aridity and vegetation on plant-wax $\delta \mathrm{D}$ in modern lake sediments, Geochim. Cosmochim. Ac., 74, 5785-5797, doi:10.1016/j.gca.2010.06.018, 2010.

Rozanski, K., Araguás-Araguás, L., and Gonfiantini, R.: Relation between long-term trends of oxygen-18 isotope composition of precipitation and climate, Science, 258, 981-985, 1992.

Sachse, D., Radke, J., and Gleixner, G.: Hydrogen isotope ratios of recent lacustrine sedimentary n-alkanes record modern climate variability, Geochim. Cosmochim. Ac., 68, 4877-4889, doi:10.1016/j.gca.2004.06.004, 2004.

Sachse, D., Radke, J., and Gleixner, G.: $\delta$ D values of individual n-alkanes from terrestrial plants along a climatic gradient - Implications for the sedimentary biomarker record, Org. Geochem., 37, 469-483, doi:10.1016/j.orggeochem.2005.12.003, 2006.

Sachse, D., Billault, I., Bowen, G. J., Chikaraishi, Y., Dawson, T. E., Feakins, S. J., Freeman, K. H., Magill, C. R., McInerney, F. A., van der Meer, M. T. J., Polissar, P., Robins, R. J., Sachs, J. P., Schmidt, H.-L., Sessions, A. L., White, J. W. C., West, J. B., and Kahmen, A.: Molecular Paleohydrology: Interpreting the Hydrogen-Isotopic Composition of Lipid Biomarkers from Photosynthesizing Organisms, Annu. Rev. Earth Planet. Sci, 40, 221-249, doi:10.1146/annurev-earth-042711-105535, 2012.

Sauer, P. E., Eglinton, T. I., Hayes, J. M., Schimmelmann, A., and Sessions, A. L.: Compound-specific D/H ratios of lipid biomarkers from sediments as a proxy for environmental and climatic conditions, Geochim. Cosmochim. Ac., 65, 213-222, 2001.

Saurer, M., Aellen, K., and Siegwolf, R.: Correlating $\delta 13 \mathrm{C}$ and $\delta 180$ in cellulose of trees, Plant Cell Environ., 20, 1543-1550, doi:10.1046/j.1365-3040.1997.d01-53.x, 1997.

Schefuß, E., Schouten, S., and Schneider, R. R.: Climatic controls on central African hydrology during the past 20,000 years, Nature, 437, 1003-1006, doi:10.1038/nature03945, 2005.

Schwamborn, G., Meyer, H., Fedorov, G., Schirrmeister, L., and Hubberten, H.-W.: Ground ice and slope sediments archiving late Quaternary paleoenvironment and paleoclimate signals at the margins of El'gygytgyn Impact Crater, NE Siberia, Quaternary Res., 66, 259-272, doi:10.1016/j.yqres.2006.06.007, 2006.

Sessions, A. L., Burgoyne, T. W., Schimmelmann, A., and Hayes, J. M.: Fractionation of hydrogen isotopes in lipid biosynthesis, Org. Geochem., 30, 1193-1200, doi:10.1016/S0146-6380(99)000947, 1999.

Sidorova, O. V., Siegwolf, R. T. W., Saurer, M., Naurzbaev, M. M., and Vaganov, E. A.: Isotopic composition $\left(\delta^{13} \mathrm{C}, \delta^{18} \mathrm{O}\right)$ in wood and cellulose of Siberian larch trees for early Medieval and recent periods, J. Geophys. Res., 113, G02019, doi:200810.1029/2007JG000473, 2008.

Smith, F. A. and Freeman, K. H.: Influence of physiology and climate on [delta] $\mathrm{D}$ of leaf wax n-alkanes from $\mathrm{C}_{3}$ and $\mathrm{C}_{4}$ grasses, Geochim. Cosmochim. Ac., 70, 1172-1187, 2006.

Sugimoto, A., Naito, D., Yanagisawa, N., Ichiyanagi, K., Kurita, N., Kubota, J., Kotake, T., Ohata, T., Maximov, T. C., and Fedorov, A. N.: Characteristics of soil moisture in permafrost observed in East Siberian taiga with stable isotopes of water, Hydrol. Process., 17, 1073-1092, doi:10.1002/hyp.1180, 2003.

Sun, Y., Clemens, S. C., Morrill, C., Lin, X., Wang, X., and An, Z: Influence of Atlantic meridional overturning circulation on the East Asian winter monsoon, Nat. Geosci., 5, 46-49, doi:10.1038/ngeo1326, 2011.

Thomas, E. K., McGrane, S., Briner, J. P., and Huang, Y.: Leaf wax $\delta 2 \mathrm{H}$ and varve-thickness climate proxies from proglacial lake sediments, Baffin Island, Arctic Canada, J. Paleolimnol., 48, 193-207, doi:10.1007/s10933-012-9584-7, 2012.

Tierney, J. E., Russell, J. M., Huang, Y., Damste, J. S. S., Hopmans, E. C., and Cohen, A. S.: Northern Hemisphere Controls 
on Tropical Southeast African Climate During the Past 60,000 Years, Science, 322, 252-255, doi:10.1126/science.1160485, 2008.

Volkman, J. K., Barrett, S. M., Blackburn, S. I., Mansour, M. P., Sikes, E. L., and Gelin, F.: Microalgal biomarkers: A review of recent research developments, Org. Geochem., 29, 1163-1179, doi:10.1016/S0146-6380(98)00062-X, 1998.

Wilkie, K., Finkelstein, D., Burns, S., Petsch, S., and BrighamGrette, J.: Continuous terrestrial Arctic record of reconstructed paleotemperature $120 \mathrm{ka}$ to present, Lake El'gygytgyn, NE Russia, in preparation, 2013.

Yang, H., Pagani, M., Briggs, D. E. G., Equiza, M. A., Jagels, R., Leng, Q., and LePage, B. A.: Carbon and hydrogen isotope fractionation under continuous light: implications for paleoenvironmental interpretations of the High Arctic during Paleogene warming, Oecologia, 160, 461-470, doi:10.1007/s00442009-1321-1, 2009.
Yershov, E. D.: General geocryology, Cambridge University Press, New York, 1998.

Yurtsev, B. A.: Botanic-geographical zonation and floristic zoning of the tundra in Chukotka, J. Bot., 58, 812-821, 1973 (in Russian).

Zhang, Z. and Sachs, J. P.: Hydrogen isotope fractionation in freshwater algae: I. Variations among lipids and species, Org. Geochem., 38, 582-608, 2007. 